\title{
De Asia a la Nueva España vía Europa: lacas asiáticas y achinadas en el siglo XVIII
}

\author{
From Asia to New Spain via Europe: Asian Lacquers and Chinoiserie in the \\ Eighteenth Century
}

Artículo recibido el Io de agosto de 20I6; devuelto para revisión el I8 de octubre de 20I6; aprobado el I8 de enero de 20I7, http://dx.doi.org/IO.2220I/iie.I8703062e.20I7.III.26II

Sonia I. Ocaña Ruiz Universidad Juárez Autónoma de Tabasco, México. ocana.r@gmail.com

Líneas de investigación El arte novohispano y sus relaciones tanto con el arte asiático como con el europeo.

Lines of research New Spanish art and its relations with both Asian and European Art.

Publicaciones relevantes

“'Enconchados': gustos, estrategias y precios en Nueva España”, Anales del Instituto de Investigaciones Estéticas XXXVII, núm. IO6 (primavera, 2015), 75-II2; "Nuevas reflexiones sobre las pinturas incrustadas de concha y el trabajo de Juan y Miguel González", Anales del Instituto de Investigaciones Estéticas XXV, núm. IO2 (primavera, 2013), I25-I76; "Mother of Pearl Inlaid Frames. The Use of Japanese Ornamentation in the Pantings of New Spain", en Donna Pierce y Ronald Otruka, eds., Asia and Spanish America: Transpasific Cultural and Artistic Exchange I500-I830 (Denver Art Museum, 2009), I29-I49 y "Marcos enconchados: autonomía y apropiación de formas japonesas en la pintura novohispana", Anales del Instituto de Investigaciones Estéticas XXX, NúM. 92 (primavera, 2008), I07-I54.

Resumen Este texto plantea que en los siglos XVII y XVIII los novohispanos se familiarizaron en los ámbitos privados con los objetos "chinos" y "achinados" mediante un proceso común de "domesticación", que involucró obras asiáticas, así como novohispanas y europeas. El estudio se concentra tanto en la producción como en el consumo de las lacas chinas y achinadas del siglo XviII. Se presta especial atención a los ejemplares achinados de técnica europea, así como al papel que desempeńaron los biombos en el fenómeno del maque achinado. A partir de un análisis documental, así como de algunos objetos conservados, se demuestra que el fenómeno del maque achinado de ningún modo se restringió a las lacas asiáticas y las novohispanas de técnica prehispánica, sino que tuvo una importante y hasta 
ahora poco estudiada diversificación en cuanto a técnicas, centros de producción y precios.

Palabras clave Maque; biombo; laca asiática; laca europea; mueble achinado; domesticación.

Abstract This paper argues that during the I7th and I8th centuries, "Chinese" and "Chinese style" objects became familiar in New Spanish domestic settings by means of a process of "domestication" that involved Asian, as well as New Spanish and European works. The article focuses on both the production and the consumption of Chinese and Chinesestyle lacquer ware from the eighteenth century. Special attention is paid to Chinese-style lacquers made following European techniques, as well as to folding screens and their role in the Chinese-style lacquer phenomenon. On the basis of documentary analysis, as well as on the study of several preserved objects, this paper demonstrates that the Chinese-style lacquer phenomenon was not restricted to Asian and New Spanish lacquers of pre-Hispanic technique, but linked to various works in terms of techniques, production centers, and prices.

Keywords Maque; folding screen; Asian lacquer; European lacquer; Chinese style furniture; domestication. 


\author{
SONIA I. OCAÑA RUIZ \\ UNIVERSIDAD JUÁREZ AUTÓNOMA DE TABASCO, MÉXICO
}

\title{
De Asia a la Nueva España vía Europa: lacas asiáticas y achinadas en el siglo XVIII
}

La domesticación de Asia y las obras "achinadas"

$\mathrm{E}$ spaña y sus territorios en América y Asia fueron uno de los agentes más importantes de la mundialización comercial y artística de la primera Edad Moderna. ${ }^{\mathrm{I}}$ En Europa circularon pocos bienes asiáticos antes del siglo Xvi; ${ }^{2}$ a finales del mismo, el comercio entre Macao, Nagasaki y Manila favoreció la adquisición de aquéllos por parte de las élites portuguesas y americanas, ${ }^{3}$ que conseguían precios más bajos que las españolas. ${ }^{4}$ En esa época, la Nueva España fue el centro de la "ruta española" del Pacífico, ${ }^{5}$ desde donde se redistribuían los productos asiáticos — principalmente chinos y

I. Rafael Dobado González, "La globalización hispana del comercio y el arte en la Edad Moderna", Estudios de Economía Aplicada 32, núm. I (2014): 20.

2. José L. Gasch-Tomás, "Globalisation, Market Formation and Commoditisation in the Spanish Empire. Consumer Demand for Asian Goods in Mexico City and Seville, ca. I57I-I630”, Revista de Historia Económica 32, núm. 2 (2014): 194.

3. Gasch-Tomás, "Globalisation", 194, y Mariano Bonialian, "México, epicentro semiinformal del comercio hispanoamericano (I680-1740)", América Latina en la Historia Económica, núm. 35 (20II): 9 .

4. Gasch-Tomás, "Globalisation", 201 y 209.

5. Bonialian, "México, epicentro". 
japoneses - a la Península, mediante regalos y encargos. ${ }^{6}$ Ya en el siglo XVII, tuvo también un papel determinante en la distribución de productos asiáticos y europeos a Sudamérica. ${ }^{7}$

Gracias al consumo de porcelanas, biombos, lacas y textiles asiáticos, ${ }^{8}$ muchos novohispanos se familiarizaron con Asia en los ámbitos domésticos (aunque de modo fragmentario); 9 esto propició que la Nueva España fuera pionera en la producción de objetos informados en los asiáticos. ${ }^{\mathrm{IO}} \mathrm{Al}$ respecto destacan los biombos, enconchados, loza vidriada y lacas, que los documentos de la época en ocasiones calificaron de "achinados". ${ }^{\text {II }}$ Aunque no se detalla lo que los novohispanos entendieron por achinado, las obras conservadas sugieren que se trata del uso de figuras, diseńos, fondos y efectos de las obras (figs. I, IO, I3, I5 y I6). En Europa y Sudamérica hubo fenómenos parecidos, aunque los objetos resultantes exhiben grandes diferencias entre sí. ${ }^{12}$

6. Gustavo Curiel, “'Al remedo de la China’: el lenguaje 'achinado’ y la formación de un gusto dentro de las casas novohispanas", en Gustavo Curiel, comp., Orientes y Occidentes: el arte y la mirada del otro. Memoria del XXVII Coloquio Internacional de Historia del Arte (México: Universidad Nacional Autónoma de México-Instituto de Investigaciones Estéticas, 2007), 299-317; Gasch-Tomás, "Globalisation", 195.

7. Mariano Bonialian, "Las aguas olvidadas de la mar del sur. Comerciantes novohispanos y sus reexportaciones de mercaderías extranjeras hacia el Perú (I680-I740)”, Historia Mexicana LXI, núm. 3 (20I2): 995-I047, y "México, epicentro".

8. Gasch-Tomás, "Globalisation”, 201.

9. Berenice Ballesteros Flores, "El menaje asiático de las casas de la élite comercial del virreinato novohispano en el siglo Xviı", Boletín del Archivo General de la Nación, núm. 20, 6 a época (2008): 59-II2.

Io. Dana Leibsohn, "Made in China, Made in Mexico", en Donna Pierce y Ronald Otsuka, eds., At the Crossroads: The Arts of Spanish America \& Early Global Trade, I492-I850: Papers from the 20Io Mayer Center Symposium at the Denver Art Museum (Denver Museum of Art, 2013), I3.

II. Curiel, "'Al remedo de la China”", 304-305.

I2. En el caso europeo, estas obras a menudo se consideran ejemplo de chinoiserie. La bibliografía al respecto es nutrida; véase, por ejemplo, Karina Corrigan, Jan van Kampen y Diercks Femcke, eds., Chinoiserie. Asia in Amsterdam: The Culture of Luxury in the Golden Age (New Haven: Yale University Press, 20I5); Oliver Impey, Chinoiserie: The Impact of Oriental Styles on Western Art and Decoration (Londres: Oxford University Press, 1977); Madeleine Jarry, Chinoiserie: Chinese Influence on European Decorative Art 17th and I8th Centuries (Nueva York: Vendome Press, 198I). Respecto a Sudamérica, véase Gauvin Alexander Bailey, "Asia en las artes de América Latina colonial”, en Joseph J. Rishel, ed., Revelaciones. Las artes en América Latina, I492-I820 (México: Fondo de Cultura Económica, 2007), 57-70, y Dennis Carr, "Chinoiserie in the Colonial Americas", en Dennis Carr, Made in the Americas. The New World Discovers Asia (Boston: Museum of Fine Arts, 2015), IIO-I3I. 
Gustavo Curiel ha sugerido que en la Nueva España se desarrolló, sobre todo durante el siglo XviII, un lenguaje artístico achinado propio, que no se explica por medio de la chinoiserie europea, y que no consideró el arte asiático como un exotismo. ${ }^{13}$ Por el contrario, en las artes útiles y decorativas de dicho siglo, la interacción de las tradiciones culturales europeas, indígenas y asiáticas — una vez asimiladas por parte de la ideología criolla— produjo la estampa distintiva de lo que hoy se entiende propiamente como el arte de la Nueva España. ${ }^{14}$

El planteamiento de Curiel es muy pertinente, pues enfatiza la originalidad de los fenómenos novohispanos, su relación con la construcción de una identidad artística propia y la falta de interés en copiar los modelos asiáticos. Ahora bien, me gustaría añadir que las obras achinadas derivan de un proceso de domesticación ${ }^{\mathrm{IS}}$ que desde principios del siglo XvII empezó a convertir los productos asiáticos de distintos orígenes, técnicas, soluciones, tamaños, calidades y precios, en artículos cuya inserción en los ámbitos domésticos virreinales resultaba cotidiana. Esta concepción de "domesticación" se relaciona con la primera definición de doméstico del Diccionario de la Real Academia: "Perteneciente o relativo a la casa u hogar" ${ }^{16}$ y remite a la familiarización con los objetos asiáticos en los ámbitos domésticos de amplios sectores sociales novohispanos.

I3. Gustavo Curiel, "Perception of the Other and the Language of 'Chinese Mimicry' in the Decorative Arts of New Spain”, en Donna Pierce y Ronald Otsuka, eds., Asia and Spanish America: Trans-Pacific Artistic and Cultural Exchange 1500-I850 (Denver Art Museum, 2009), 20. I4. Curiel, "Perception of the Other", I9 y 20.

I5. Las primeras versiones de estas reflexiones aparecen en las ponencias "New Spanish Domestication of Asia: the Case of Enconchados" y "La domesticación de Asia: las lacas y la construcción de las identidades artísticas novohispanas", presentadas respectivamente en los coloquios Hybrid Creations Trade Between Europe, the Americas and Asia and its Transcontinental Impact on Art in the Early Modern Age of Globalisation y 450 años del tornaviaje. Las implicaciones de los contactos transpacificos, en septiembre y octubre de 20I5. Recientemente, Anne Gerritsen ha recurrido también al término domesticación para estudiar el impacto de las conexiones con Asia, África y América en la cultura material holandesa del siglo xvir a escala doméstica. Más allá de la coincidencia en cuanto al uso del término, Gerritsen se refiere al consumo de bienes de origen extranjero, más que a sus apropiaciones en las producciones locales. "Domesticating Goods from Overseas: Global Material Culture in the Early Modern Netherlands", Journal of Design History, Io de agosto de 20I6, I-I7, consultado el 5 de septiembre de 20I6, en http://jdh.oxfordjournals. org/content/early/20I6/o8/ıo/jdh.epwo2I.abstract.

I6. Consultado el ro de septiembre de 2015 en http://dle.rae.es/. 
Las numerosas aproximaciones novohispanas al arte chino y japonés se fundamentan en una fuerte voluntad de familiarizarse con esas partes de Asia a partir de los objetos. ${ }^{17}$ Dicho acercamiento no es exclusivo de la Nueva Espańa, ni de los objetos asiáticos. Sin embargo, me gustaría plantear que la domesticación no sólo consiste en la elaboración de obras novohispanas informadas en las asiáticas, sino también en su consumo junto con el de objetos presumiblemente de origen asiático y europeos achinados, que corresponden a un deseo común de incorporar formas y soluciones asiáticas a la propia cotidianidad.

Desde luego, los términos en los que se produjo esta incorporación variaron en cada caso, pero es destacable que en varias ciudades novohispanas amplios sectores de la población consumieron cotidianamente bienes asiáticos y achinados ${ }^{18}$ es decir, lejos de ser una moda pasajera al alcance de una minoría, tanto los objetos asiáticos como los achinados se fueron transformando, diversificando y adaptando a las necesidades de un mercado que, al parecer, siguió creciendo durante toda la época virreinal, y moldeó parte importante de su economía. ${ }^{19}$

La producción de objetos achinados no necesariamente obedece al desabasto o a los altos precios de los bienes asiáticos, pues en la Nueva España circularon muchas obras de precios diversificados. ${ }^{20}$ Por otro lado, esta producción tampoco se explica sólo a partir del fácil acceso a los objetos asiáticos; de otro modo, las obras achinadas habrían sido muy parecidas en todos los ámbitos donde circuló el arte asiático. A diferencia de lo que en ocasiones ocurre en Europa no se conocen, hasta el momento, obras novohispanas que inten-

17. Ballesteros Flores, "El menaje asiático", 9I.

I8. Aunque el caso más conocido es el de la Ciudad de México, se sabe del consumo no sólo en otras ciudades grandes, como Puebla, sino incluso en otras mucho más pequeñas, como Parral (Chihuahua) y Colima. Véase Gustavo Curiel, "Cuatro inventarios de bienes de particulares del Real y Minas de San José de Parral”, Actas del Segundo Congreso de Historia Regional Comparada (Universidad Autónoma de Ciudad Juárez, I99I), 249-279, así como Paulina Machuca, "De porcelanas chinas y otros menesteres. Cultura material de origen asiático en Colima, siglos XVIXVII", Relaciones, núm. I3I (verano, 20I2): 77-I34.

19. Mariano Bonialian, "La seda china en Nueva España a principios del siglo Xvir. Una mirada imperial en el Memorial de Horacio Levanto", Revista de Historia Económical Journal of Iberian and Latin American Economic History, DoI:I0.I017/So212610915000385, 4, 5, I4 y 16.

20. Bonialian, "La seda china", I3 y I6. 
ten copiar fielmente las soluciones asiáticas. ${ }^{21}$ Esto no se debe a una incapacidad artística, sino a que el mercado novohispano se aficionó a lo achinado tanto como a lo chino. ${ }^{22} \mathrm{Al}$ parecer, las obras asiáticas y las achinadas convivieron en los mismos ajuares a lo largo de todo el periodo virreinal; el gusto por ambas trasciende el mero poder adquisitivo, pues coexisten tanto en inventarios de bienes ricos, ${ }^{23}$ como en otros más austeros. ${ }^{24}$

Todo parece indicar que en el México virreinal no se intentó profundizar en el conocimiento de las obras asiáticas, ni hubo salones chinos o japoneses dedicados a la exhibición de dichas obras. ${ }^{25}$ Incluso en los ajuares que incluyeron muchos objetos asiáticos, éstos se conservaron junto a otros novohispanos y europeos no achinados. En los ámbitos domésticos novohispanos, las obras asiáticas se resignificaron al desplegarse en contextos cuyo interés prioritario rebasó el alarde de familiaridad con el arte asiático. El gusto por dicho arte y su uso como fuente de inspiración fueron selectivos; por ejemplo, los biombos

2I. Al respecto destaca esta referencia de Alberto Baena Zapatero: "En 167I, Antonio García Fragoso, residente de Puebla, tenía dos rodaestrados hechos con 'algodón de China', uno de ellos en 'doble tafetán de la tierra'. Se trata, por tanto, de un ejemplo de mueble oriental producido en Nueva España con material importado de China, pero con un estilo completamente distinto al del original" ("In I671, Antonio García Fragoso, a resident of Puebla, had two rodaestrados made with 'cotton from China', one of them in 'double taffeta de la tierra'. Here, therefore, is an example of a piece of Oriental furniture produced in New Spain with material imported from China, but with a completely different style from the original") (trad. de la autora), en "Chinese and Japanese Influence on Colonial Mexican Furniture: The Achinado Folding Screens", Bulletin of Portuguese-Japanese Studies, 20 (junio, 2010): I2I.

22. Curiel, "Perception of the Other", 20.

23. Los casos más conocidos son el de la marquesa de San Jorge y el del conde de Xala, de los siglos XVII y XVIII, respectivamente. Véase Gustavo Curiel, "El efímero caudal de una joven noble. Inventario y aprecio de los bienes de la marquesa dońa Teresa Francisca María de Guadalupe Retes Paz Vera (Ciudad de México, I695)”, Anales del Museo de América, núm. 8 (2000), y Manuel Romero de Terreros, Una casa del siglo XVIII en México, Estudios y Fuentes del Arte en México (México: Universidad Nacional Autónoma de México-Instituto de Investigaciones Estéticas, 1957).

24. Tal es el caso, por ejemplo, del "Inventario de bienes de doña María Gelacia y Altamirano difunta (I708)", Archivo General de la Nación (en adelante AGN), Civil, vol. II5, exp. 2.

25. Sin embargo, al parecer en el siglo xvir llegó a haber gabinetes destinados exclusivamente a exhibir obras asiáticas. Gustavo Curiel, "De cámaras de maravillas, aparadores y escaparates de curiosidades, mostradores de plata y cristales, estantes y gabinetes: los embriones del coleccionismo en la Nueva España”, en Óscar Flores, coord., El clasicismo en la época de Pedro José Márquez (I74II820): arqueología, filología, historia, música y teoría arquitectónica (México y Madrid: Universidad Nacional Autónoma de México-Instituto de Investigaciones Estéticas/Real Academia de Bellas Artes de San Fernando, 20I4). 
tuvieron especial arraigo, y aunque algunos fueron achinados, otros soslayaron cualquier parecido con los asiáticos, más allá de su estructura. ${ }^{26}$

Tanto en Europa como en América, el gusto por los objetos asiáticos se relacionó con cierta búsqueda de ostentación y prestigio. Hacia I600, la adquisición de objetos asiáticos era un lujo en la Ciudad de México; ${ }^{27}$ al respecto destacan las lacas, sobre todo las japonesas, reconocidas como las de mayor calidad. ${ }^{28}$ Sin embargo, a lo largo de los siglos XVII y XVIII, tanto las lacas asiáticas como las achinadas diversificaron sus usos, precios, calidades, técnicas e iconografías. En ocasiones, la idea de lujo asiático ${ }^{29}$ convivió con la de intimidad; por ejemplo, en los biombos de cama, que incluyen ejemplares de laca china y achinados. ${ }^{30} \mathrm{El}$ hecho de que éstos no estuvieran destinados a exhibirse en público es muy significativo, pues demuestra que lo achinado se había domesticado al punto de alcanzar los espacios más íntimos de la casa.

26. Al parecer, en España en el siglo Xviı se adopta la moda europea de desmontar biombos para decorar salones. Cristina Ordóñez Goded, "De lacas y charoles en España: siglos XVI-XIX”, tesis doctoral (Universidad Complutense de Madrid-Facultad de Geografía e Historia-Departamento de Historia del Arte II [Moderno], 20I6), 232. Por su parte, los novohispanos exhiben los biombos completos y los domestican de otros modos, como sugieren las referencias a biombos criollos. Véase Gustavo Curiel, "Los biombos novohispanos: escenografías de poder y transculturación en el ámbito doméstico", en Viento detenido. Mitologías e historias en el arte del biombo (México: Museo Soumaya, 1999), 26.

27. Gasch-Tomás, "Globalisation", 197.

28. Gerald W. R. Ward, "Lacquer”, The Grove Encyclopedia of Materials and Techniques in Art (Oxford University Press, 2008), 329, y Monika Kopplin, "Preface", "Lacquerware in Asia: China, Korea, Japan and the Ryukyu Islands", en Monika Kopplin, ed., Lacquerware in Asia, Today and Yesterday (Unesco Publishing, Memory of Peoples, The Intangible Heritage, 2002), 20. Agradezco a Monika Kopplin, directora del Museum für Lackkunst de Münster, Alemania, su generoso apoyo durante mi visita a dicho museo en el transcurso de la investigación de la que surge este texto.

29. Jessica Keating y Lia Markey han señalado que en los documentos de los Habsburgo y los Medici, el término "indio" es polisémico, y podía denotar riqueza, además de la procedencia o el estilo del objeto. "Indian' Objects in Medici and Austrian-Hungarian Inventories", Journal of the History of Collections Advance Access (I6 de diciembre, 20IO): I5. Como se verá, la lectura de algunos inventarios novohispanos sugiere algo parecido en relación con los objetos "chinos".

30. Quizá el ejemplo más famoso sea el que José de Páez representó en el exvoto con la Virgen de los Dolores de Xaltocan, discutido en Gustavo Curiel y Antonio Rubial, "Los espejos de lo propio: ritos públicos y usos privados en la sociedad virreinal", en Pintura y vida cotidiana en México I650-I950 (México: Fomento Cultural Banamex/Consejo Nacional para la Cultura y las Artes, 1999), I48-I49. 
En los siglos XVI y XVII, las lacas de mayor circulación en la Nueva España deben de haber sido las japonesas, ${ }^{3 \mathrm{I}}$ pero a partir de 1700 las chinas dominaron el mercado internacional. Este estudio se concentra en el siglo xviII, cuando la circulación de lacas asiáticas se incrementó en buena parte de Europa; ${ }^{32}$ como consecuencia aumentó la producción de lacas europeas achinadas, que a la vez impactó en las producciones novohispanas. Esta circunstancia dio pie a nuevas obras, deliberadamente distintas a las europeas achinadas. De ahí que en el siglo XVIII, al igual que en el XVII, el México virreinal haya exportado sus propias versiones de lacas achinadas, ${ }^{33}$ con una conciencia de la propia originalidad artística producto de los procesos de domesticación de las obras.

\section{Las lacas achinadas en la Nueva España. Una aproximación historiográfica}

En la Nueva España, el fenómeno de las lacas no sólo comprendió las obras hechas con técnicas de origen asiático y prehispánico, sino también los enconchados, los muebles pintados, las lacas de técnica europea, los biombos y acaso otros tipos de trabajo. ${ }^{34}$ Todas las técnicas europeas y novohispanas se usaron, en ocasiones, para hacer obras achinadas. Su diversidad impide incluir aquí una revisión exhaustiva de todas ellas. El interés de este trabajo es discutir temas poco estudiados; en particular, el papel de Europa como fuente de técnicas y de obras de laca y el papel que desempeñaron los biombos en el fenómeno del maque achinado. La discusión se concentrará en el siglo XVIII, porque ambos fenómenos son más marcados durante este siglo.

3I. Téngase en cuenta que en esa época los portugueses controlaron la circulación de lacas japonesas y que las obras llegaron a la Nueva España a través de Manila. Respecto a la circulación de obras japonesas en la Nueva España en el siglo Xviı véase, por ejemplo, Gustavo Curiel, "Los biombos novohispanos", IO-I2, y Sofía Sanabrais, "The Spaniards of Asia: The Japanese Presence in Colonial Mexico", Bulletin of Portuguese-Japanese Studies, vols. I8-I9 (junio-diciembre, 2009): 223-25I.

32. Véase Maxine Berg, "In Pursuit of Luxury: Global History and British Consumer Goods in the Eighteenth Century", Past and Present, núm. I82 (2004): 86, y Kopplin, "Lacquerware in Asia”, 45 .

33. Véase algunas reflexiones al respecto en Baena Zapatero, "Chinese and Japanese", I22-I23.

34. En el siglo XVI, la circulación de lacas en la Nueva España correspondió principalmente a las obras japonesas, así como a las jícaras y bateas de Michoacán, mientras que en el Xvir abarcó también las lacas chinas y los enconchados, y en el xvıI incluyó, además de las anteriores, las lacas europeas achinadas, así como las novohispanas de técnica europea y los biombos y otros muebles pintados al remedo de maque. 
Para entender mejor la problemática de las lacas "chinas" y achinadas es necesario combinar el análisis de los documentos y de las obras conservadas. Pese a que las referencias documentales al maque chino menudean en los ámbitos domésticos, en México se han conservado pocas lacas asiáticas. ${ }^{35}$ La existencia de biombos "chinos" de maque rojo, mencionados en muchos documentos, queda constatada en los numerosos biombos rojos achinados que se conservan. De hecho, se conocen varias decenas de lacas novohispanas achinadas, ${ }^{36}$ pese a que las referencias documentales a ellas son mucho menos numerosas que aquéllas al maque chino (véase tabla I). No obstante, no es seguro que los documentos identificaran correctamente el origen de las lacas que denominaron chinas; de cualquier modo, las reiteradas referencias a ejemplares chinos y achinados demuestran que el maque novohispano y el asiático estuvieron estrechamente relacionados.

Cabe señalar que la producción y el consumo novohispano de lacas no se fundamentan únicamente en las obras asiáticas, pues ni las lacas virreinales ni las europeas se valoraron sólo a partir del parecido con aquéllas, y se conservan muchos ejemplares no achinados. ${ }^{37}$ Entre las lacas achinadas, algunas introducen un buen número de figuras de origen chino o japonés (figs. IO, I3 y I6), mientras que otras sólo incorporan algunos detalles a los modelos occidentales (fig. I). Las menciones documentales al maque achinado, o al remedo de la China, incluyen bateas, baúles, cajas y escribanías de probable origen michoacano y guerrerense. Sin embargo, también se registran objetos de mayor tamaño, tales como roperos, escritorios y biombos, cuyas técnicas y ámbitos de producción deben ser distintos.

35. La cantidad exacta se ignora, pues la mayoría de las obras se halla en colecciones particulares. Sin embargo, las obras reproducidas en las publicaciones mexicanas apenas alcanzan la treintena. Desde luego debe de haber más, pero no hay duda de que su número es muy inferior al que se conserva en España, no sólo en colecciones particulares, sino también eclesiásticas.

36. Esta estimación se basa principalmente en la revisión de las obras registradas en Sonia Pérez Carrillo, La laca mexicana: desarrollo de un oficio artesanal en el virreinato de la Nueva España durante el siglo XVIII (Madrid: Alianza/Ministerio de Cultura/Dirección General de Cooperación Cultural, 1990), así como en Teresa Castelló Yturbide, El arte del maque en México (México: Fomento Cultural Banamex, 1980) y Teresa Castelló Yturbide y Marita Martínez del Río, Biombos mexicanos (México: Instituto Nacional de Antropología e Historia, 1970).

37. Véase los ejemplares reproducidos en Pérez Carrillo, La laca mexicana; Castelló Yturbide, El arte del maque y Patricia Acuña Castrellón, El maque o laca mexicana, la preservación de una tradición centenaria (Zamora: El Colegio de Michoacán-Fideicomiso "Felipe Teixidor y Montserrat Alfau de Teixidor", 20I2). 
I. Ropero ¿llaca, pintura imitando

maque?, Nueva España, siglo XVIII, $230 \times 156 \times 74 \mathrm{~cm}$. Museo Franz Mayer,

México. Imagen cortesía del Museo Franz Mayer.

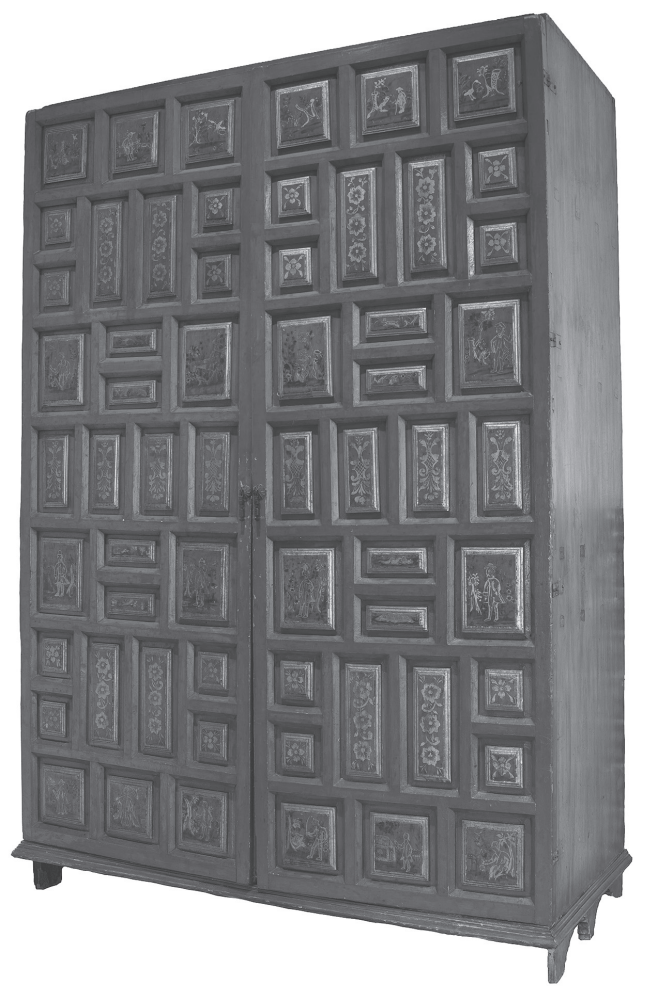

Las referencias a la relación entre el maque asiático y el michoacano y guerrerense empezaron a principios del siglo xx. Pese a que muchas lacas michoacanas y guerrerenses no muestran puntos de contacto con las asiáticas, en I92I Gerardo Murillo afirmó la presencia china en la costa occidental de México, a partir de la observación de las lacas de Olinalá y Uruapan, ${ }^{38}$ que le parecieron muy semejantes a las chinas tanto técnica como formalmente. ${ }^{39}$ Esta opinión tuvo pocos partidarios. En 1939, el moreliano Francisco P. de León subrayó las diferencias técnicas entre ambas y sugirió que el parecido se debía a la profusa llegada de objetos asiáticos a la Nueva España. ${ }^{\circ} \mathrm{A}$ la vez, De León señaló

38. Gerardo Murillo, "Los chinos fueron los descubridores de nuestra patria”, Excélsior, 22 de mayo de I92I.

39. Murillo, "Los chinos fueron los descubridores".

40. Francisco P. de León, Los esmaltes de Uruapan (México: DAPP, 1939), 59 y 63. La idea la retomó José Guadalupe Zuno, en Las Ilamadas lacas michoacanas de Uruapan no proceden de las orientales (Guadalajara: ed. particular, 1953). 
la relación con el arte europeo; sin embargo, no se refirió a los muebles o lacas, sino a los esmaltes, mosaicos y trabajos de orfebrería del Viejo Mundo. ${ }^{4 \mathrm{I}}$

Esto sugiere que el autor no conocía las lacas europeas, pero estaba consciente de que el gusto por las superficies lustrosas era común al arte de dicho origen. En la época en que escribió esta obra, 1922, el estudio de las lacas europeas aún no se había desarrollado. En realidad, la circulación de dichas lacas en la Nueva España apenas se había mencionado hasta 1980, y su relación con los ejemplares novohispanos achinados representa una pequeña parte de la historiografía. El estudio de las lacas españolas es aún incipiente y hasta ahora el único que ha abordado extensamente la producción y circulación de lacas en España es la tesis doctoral de Cristina Ordóñez Goded (2016).42

En las décadas de los sesenta y setenta, la revista Artes de México dedicó números a los muebles, así como al maque y al galeón de Manila, en los que dio a conocer varios ejemplares de laca achinada, ${ }^{43}$ y se hicieron referencias técnicas a las obras de Michoacán, Guerrero y Chiapas. También se documentó a la familia De la Cerda, ${ }^{44}$ activa en Pátzcuaro a mediados del siglo XviII y especializada en la producción de lacas achinadas, entre las que destacan las bateas.

Si bien estas publicaciones reprodujeron algunos biombos chinos y achinados de laca, la discusión sobre éstos aparece propiamente en la historiografía en 1970, con la publicación del libro Biombos mexicanos de Teresa Castelló Yturbide y Marita Martínez del Río de Redo. Ahí se comenta un "biombo mexicano imitando laqueado chino", datado a finales del siglo XVII o principios del XVIII y decorado en dorado con fondo bermellón. ${ }^{45}$ Las autoras no se pronuncian sobre su técnica o lugar de elaboración, pero señalan como hechos en Pátzcuaro un biombo que representa a Felipe Ventrando a Madrid y otros dos del siglo XviıI que representan la Ciudad de México. ${ }^{46}$ La sugerencia de que estos biom-

4I. De León, Los esmaltes de Uruapan, 77-83.

42. Ordóńez Goded, "De lacas y charoles".

43. Las obras aparecieron en los números Artes de México. El mueble mexicano, núm. II8 (1969); Artes de México. El galeón de Manila, núm. I43 (1971) y Artes de México. El maque: lacas de Michoacán, Guerrero y Chiapas, núm. I53 (1972).

44. Mercedes Fernández Castelló, "Los De la Cerda en Michoacán”, Artes de México. El maque. Lacas de Michoacán, Guerrero y Chiapas, 27-32.

45. Castelló Yturbide y Martínez del Río de Redo, Biombos mexicanos, 65.

46. Castelló Yturbide y Martínez del Río de Redo, Biombos mexicanos, 76 y 86. La idea de que Pátzcuaro fue un centro productor de biombos se retoma al hablar de las técnicas de laca ahí usadas, I53. Las autoras también documentan las técnicas de laca asiáticas y las novohispanas de origen prehispánico, I45-162. 
bos eran de Pátzcuaro se explica en parte por la falta de información sobre los biombos europeos de laca que, como se verá, circularon en la Nueva España y cuyas técnicas podrían haberse usado localmente. ${ }^{47}$ Aunque se ha reconocido la importancia que los biombos de laca tuvieron en el México virreinal, ${ }^{4}$ hasta ahora no se sabe qué técnicas emplearon.

La idea de que los talleres de laca de técnica prehispánica incursionaron en la realización de biombos se mantiene arraigada entre algunos investigadores, ${ }^{49}$ pese a la falta de evidencias al respecto. Puesto que José Manuel de la Cerda hizo obras por encargo, ${ }^{\circ}$ no sería imposible que hubiera elaborado biombos. Sin embargo, su producción documentada comprende objetos pequeños, y los biombos achinados de maque aparecen en los inventarios con regularidad, lo cual sugiere que se hicieron en talleres dedicados principalmente a su elaboración, acaso en ciudades como México.

En 198I, Castelló publicó un libro sobre lacas, en su mayor parte dedicado a las de Michoacán y Guerrero. En este caso se omiten los biombos de laca; esto supone un avance respecto a los planteamientos de Biombos mexicanos, al advertir que no corresponden a esa producción. Castelló se refiere a algunos muebles achinados del inventario de bienes del conde de Xala, que "equivalen a los que se hicieron en Europa cubiertos de chinoiseries, aunque con técnica diferente" ${ }^{5 \mathrm{SI}} \mathrm{El}$ conocimiento de las lacas europeas — y la idea implícita de que podrían haberse conocido en la Nueva España - ya era patente al principio de la obra, donde se menciona la técnica francesa del vernis martin. ${ }^{52}$ Aunque Cas-

47. Ordóńez Goded, "De lacas y charoles”, 78.

48. Gustavo Curiel ha demostrado que esas obras proliferan en los documentos del siglo XviII, mientras que Alberto Baena Zapatero ha hallado documentos de finales de ese siglo que sugieren la existencia de producciones chinas o filipinas de paneles de laca roja destinadas específicamente al mercado novohispano. Curiel, "Los biombos", 24-32 y Baena Zapatero, "Un ejemplo de mundialización: El movimiento de biombos desde el Pacífico hasta el Atlántico (siglos XVII-XVIII)”, Anuario de Estudios Americanos 69, núm. I (2012): 37-38 y "Chinese and Japanese", I05 y I07. 49. Pérez Carrillo, La laca mexicana, 49, y Alberto Baena Zapatero, "Apuntes sobre la elaboración de biombos en Nueva España”, Archivo Español de Arte LXXXVIII, núm. 350 (abril-junio 20I5): I8I-I83.

50. Es bien conocida la cita de fray Francisco de Ajofrín, quien tras ponderar el trabajo de José Manuel de la Cerda en Pátzcuaro añadió: "Vi una docena de bateas grandes de fresno que estaba pintando para la excelentísima señora marquesa de Cruilles, virreina de Méjico, dignas de la persona de tan elevado carácter", en Francisco de Ajofrín, Diario del viaje que hizo a la América en el siglo XVIII el P. Fray Francisco de Ajofrín (México: Instituto Cultural Hispano-Mexicano, 1964), I60.

5I. Castelló Yturbide, El arte del maque, II.

52. Castelló Yturbide, El arte del maque, io. 
telló no mencionó explícitamente la circulación de lacas francesas en la Nueva España, estas breves referencias son muy relevantes, pues suponen una de las primeras apariciones de las lacas europeas - y su posible relación con las novohispanas - en la historiografía mexicana. El año anterior, Xavier Moyssén había publicado el manuscrito "Secretos de lacas, charoles y colores", que había localizado en una biblioteca mexicana y fue, como se verá, uno de los más importantes tratados europeos de laca del siglo XviII.

En 1987 Sonia Pérez Carrillo acertó al advertir que las lacas inglesas achinadas habían tenido cierto impacto sobre los muebles novohispanos que imitaron las lacas orientales mediante técnicas europeas que habían convivido con el maque de origen prehispánico..$^{53}$ En realidad, este último también muestra el impacto de la chinoiserie europea, como ha señalado Gustavo Curiel, quien las considera claros ejemplos de una combinación ornamental tripartita, o triple identidad "mestiza", que sugieren la posibilidad de que el artista haya visto y usado como modelos algunas piezas europeas. ${ }^{54}$

El avance de la discusión sobre el alcance de las lacas europeas achinadas en las novohispanas se debe en buena medida a estos últimos autores. Como se ha visto, Curiel también ha aportado una aproximación teórica que enfatiza la existencia de múltiples manifestaciones del interés novohispano por lo achinado. En este texto se pretende abonar a la discusión a la luz de nuevos hallazgos documentales, así como de información técnica que no se había mencionado. Asimismo, se plantearán algunas hipótesis sobre los biombos de maque, que gustaron particularmente en la Nueva España y sobre los que aún existen incógnitas.

Antes de concluir esta síntesis historiográfica, cabe señalar que en los últimos años se han hecho importantes aportaciones al conocimiento técnico de las lacas de origen prehispánico. Recientemente Patricia Acuña publicó un libro que incluye análisis técnicos a varios ejemplares virreinales, que demuestran que los procedimientos sufrieron grandes variaciones. ${ }^{55}$ Algo parecido se ha advertido con relación a las técnicas asiáticas y europeas pues, a medida que

53. Sonia Pérez Carrillo, "Imitación de la laca oriental en muebles novohispanos del siglo xvıII", Cuadernos de Arte Colonial, núm. 3 (1987): 51, 52 y 59. Su posición tiene especial valor, pues no todos los autores la compartían. Por ejemplo, en opinión de José Ignacio Conde y Díaz Rubín, "se ha exagerado la influencia de Inglaterra sobre Nueva España en cuanto a la enorme diversidad de muebles [que] denominamos genéricamente 'chippendale mexicano'". "Un excepcional mueble mexicano del siglo xviII", Artes de México, El mueble mexicano, núm. iı8 (I969): 35.

54. Curiel, "Perception of the Other", 22.

55. Acuña Castrellón, El maque, 122. 
se estudian más ejemplares, se advierten importantes variaciones, así como la combinación de distintas técnicas en las mismas obras; ${ }^{56}$ es decir, los lacadores de todos los ámbitos geográficos se esforzaron de manera constante por adaptar su trabajo a las necesidades del mercado.

\section{El maque y la pintura}

Aunque el uso del término laca se encuentra generalizado en nuestros días, ${ }^{57}$ la mayoría de los documentos novohispanos emplean el de "maque". Según Joan Corominas, "Ha de tratarse de la misma palabra que el portugués maquié ‘barniz japonés de oro o plata', documentado desde I684 (Dalgado) y procedente del japonés makie, parcialmente confundido en castellano con laca (lacre, fr. laque)" ${ }^{58} \mathrm{La}$ referencia tiene sentido si se toma en cuenta que a finales del siglo XVI los portugueses fueron los principales importadores de laca asiática, y que la más codiciada era la japonesa. ${ }^{59}$ Sin embargo, a partir del siglo XvII los documentos novohispanos asociaron el término maque a distintos objetos asiáticos, virreinales y europeos.

Esta polisemia no siempre ha sido tenida en cuenta por la historiografía, pues se ha sugerido que el término maque designó, específicamente, las obras novohispanas de herencia indígena. ${ }^{60} \mathrm{El}$ maqueado de jícaras, tecomates y otros objetos surgió en Mesoamérica y continuó a la llegada de los españoles, sobre todo en Peribán, Uruapan y Pátzcuaro (Michoacán), así como en Olinalá (Guerrero). Como han advertido varios autores, en el siglo Xvi ese trabajo

56. Ordónez Goded, "De lacas y charoles", 40-42, y "Lacquer Analysis: Layer by Layer", The Getty: A World of Art, Research, Conservation, and Philanthropy (verano, 2013): 9-IO.

57. El tema se discute ampliamente en Ordóńez Goded, "De lacas y charoles", II9-I73.

58. Joan Corominas, Diccionario crítico etimológico castellano e hispánico, vol. III (Madrid: Gredos, 1980), 836.

59. Entre los autores de la época que seńalan la calidad superior de la laca japonesa destaca João Rodrigues, História da Igreja do Japão... iniciada en 1575 (Macao, I622, vol. II), 2I-23.

6o. De León, Los esmaltes de Uruapan, 37; Acuña Castrellón, El maque, 21-22; Dennis Carr, "Chinoiserie", II6. Por su parte, Castelló Yturbide empieza su estudio sobre la producción virreinal señalando "El maque o laca es una antiquísima técnica artística y artesanal con dos vertientes principales; la asiática y la mexicana", El arte, 5. Sin embargo, a lo largo de su texto nunca se refiere a las obras asiáticas como maque, sino como lacas y, a la inversa, usa casi exclusivamente el término maque para designar la producción mexicana. 
no se denominó maque, sino que se asoció a la pintura y barnices; ${ }^{61}$ no obstante, a partir de 1600 los documentos capitalinos lo incluyen como parte de aquél considerado como maque. ${ }^{62}$

Ahora bien, el Diccionario de la Real Academia Española no recogió este significado de "maque" sino hasta I884, cuando lo definió como "Barniz durísimo e impermeable, compuesto de resinas y jugos de plantas asiáticas y de otros varios elementos. Zumaque del Japón" ${ }^{63}$ A continuación, definió maquear como "Adornar muebles, utensilios y otros varios objetos con pinturas o dorados, usando para ello el maque. Es industria asiática y las imitaciones se hacen en Europa con barniz copal blanco". ${ }^{64}$

La mención a las obras europeas, técnicamente distintas y hechas a imitación de las asiáticas, demuestra que el término designó obras elaboradas con distintos materiales y procedimientos. Es decir, el uso del término maque alude a un efecto, al margen del origen o la técnica. Algo parecido se advierte en relación con el término charol, ${ }^{65}$ preferido en España y esporádicamente empleado

6I. Entre las referencias más conocidas se hallan las de Jerónimo de Mendieta, Torquemada, Antonio de Ciudad Real, fray Matías de Escobar, el padre Pablo Beaumont y el cura Joaquín Alexo de Meabe. Véase una síntesis actualizada en Acuña Castrellón, El maque, 24-37. Cabe añadir que en 1863, al referirse a Uruapan, Antonio García Pérez señaló: "Una de las industrias de aquellos indígenas, es lo que allí se conoce con el nombre de pintura, cuya arte les enseñó el obispo Quiroga [y] comprende el modo de preparar las jícaras, bandejas y guajes, pintarlos, esculpirlos o dorarlos [...] conservándose después de mucho en buen estado."Antonio García Pérez, "Descripción de la ciudad de Uruapan en el departamento de Michoacán”, Boletín de la Sociedad Mexicana de Geografia y Estadistica (I863): 475 .

62. Al respecto destaca "Una caja de maque de Michoacán, al remedo de la China”. Curiel, "Al remedo de la China”, 305 .

63. Diccionario de la Real Academia Española (Madrid: imprenta de D. Gregorio Hernando, I884), 677, consultado el II de enero de 20I6, en http://web.frl.es/DA.html. La palabra maque aparece en el Diccionario de Terreros de 1787 , pero su definición es ajena a nuestras obras, pues se refiere a un "insecto de América, parecido al zancudo, aunque mucho mayor, e incomparablemente más inoportuno, de modo que en ciertos tiempos del ańo algunos indios se van para liberarse de él a vivir en medio del agua", en Esteban Terreros y Pando, Diccionario castellano, t. II (Madrid: imprenta de la viuda de Ibarra, 1787), 523, consultado el ro de enero de 2016, en http://web.frl.es/Da.html

64. Diccionario de la Real Academia Española (Madrid: imprenta de D. Gregorio Hernando, I884), 677, consultado el II de enero de 20I6, en http://web.frl.es/DA.html.

65. El Diccionario de Autoridades lo definió en 1729 como "Barniz que de cierta goma de China y Japón hacen los chinos, lustrosissimo, duro, y vistoso. Resiste al agua, y à toda inclemencia, y solo se deshace al fuego, sin el qual es de larguissima duracion. Son mui estimadas las piezas guarnecidas de este betún: y aunque los ingleses y holandeses han intentado contrahacerle con 
en la Nueva España, al parecer con la misma significación que maque, ${ }^{66}$ aunque las definiciones del diccionario refieren algunas variaciones entre ambos. ${ }^{67}$ Como se verá adelante, las lacas europeas se diversificaron técnicamente y circularon en la Nueva España, donde se les consideró maques. Por otro lado, aunque el Diccionario de Autoridades omite los trabajos michoacanos y guerrerenses - cuya base eran los minerales pulverizados, la grasa extraída de la hembra del axe y el aceite de chía o el de linaza—, la mera referencia a varios tipos de lacas sugiere una flexibilidad digna de atención.

La asociación entre maque y pintura no es exclusiva de los trabajos michoacanos y guerrerenses. Por ejemplo, hay menciones documentales a "Dos escritorios de maque de China negros, pintados de flores de colores y pájaros, de media vara de alto y media de ancho, en sesenta pesos ambos"; 68 "Una silla de manos, nueva, pintada de maque azul, y por dentro de raso de China listado, que se apreció en cuarenta pesos" 69 e "Yttem un rodastrado de diez tablas, maqueado, pintado y dorado, nuevo, en quince pesos". ${ }^{70}$ Así pues, el maque pintado comprendió obras chinas y europeas, o novohispanas de técnica europea, pues las sillas de manos de laca corresponden a la producción de los carroceros. En cuanto al rodastrado, aunque su origen es incierto, no se conocen refe-

la misma goma, que han trahído del Oriente, no han conseguido la perfección, ni en el lustre, ni en la duración [...] Otro barniz se hace muy peregrino, para imitar el charol que viene de la India”, Diccionario de la lengua castellana [...], t. II: Que contiene la letra C (Madrid: imprenta de Francisco del Hierro, I729), 3IO, consultado el II de enero de 20I6, en http://web.frl.es/DA.html.

66. En la Nueva España dicho término sólo se ha registrado en el inventario de bienes del conde de Xala, de 1784: "Una bandeja de charol, de siete ochavas de largo, en 25 pesos", Manuel Romero de Terreros, Una casa del siglo XVIII, 62. La fuente también menciona una decena de objetos de maque chinos, europeos y posiblemente novohispanos. La significación de ambos términos parece ser la misma; "maque" se empleó para nombrar una mesa china de tablero de damas y libro; un tocador; dos roperos; dos relojes (uno de ellos atribuido a Ellicott); dos biombos chinos y dos almohadillas. Romero de Terreros, Una casa del siglo XVIII, 56-58 y 60-6I.

67. Por otro lado, la laca aparece en el Diccionario de Autoridades desde 1734, pero no en los documentos aquí registrados. En dicha fuente se describen la goma laca de origen animal, natural de la India, así como las lacas de Sián y Pegú — hoy Tailandia y Birmania—, de base vegetal. Diccionario de la lengua castellana [...] t. IV, Que contiene las letras G-N (Madrid: imprenta de Francisco del Hierro, I734), 345, consultado el II de enero de 20I6, en http://web.frl.es/DA.html.

68. AGN, Civil, "Inventario de bienes de Juan de la Rea, Caballero de la orden de Alcántara (I708)", vol. I37, exp. I, f. 29.

69. Curiel, "Introducción", en El mobiliario en Puebla: preciosismo, mitos y cotidianidad de la carpintería y la ebanistería (Puebla: Fundación Mary Street Jenkins, 2009), 28.

70. AGN, Notaría 19, Ariza y Valdés, "Carta de dote Joseph de Vasquez (I728)", vol. I25, f. I70v. 
rencias novohispanas a los talleres de laca michoacanos y guerrerenses como productores de ese tipo de muebles, por lo que debe tener otra procedencia.

La relación entre maque y pintura se constata en el tratado de Antonio Palomino (1715), que al describir la "pintura embutida plástica" se refiere a las lacas mexicanas, así como a las europeas y detalla sus diferencias técnicas. ${ }^{71}$ Por otro lado, algunos documentos novohispanos omiten tanto el término maque como el de pintura, pero por el tipo de objeto, lugar de producción, cronología y paleta inferimos que se trata de maques; por ejemplo: "Yt. otro dicho [escritorio] de Michoacán, dorado sobre negro en ocho pesos"; 72 "Yt dos ternos de escritorios de Michoacán dorados, a diez y seis pesos, montan treinta y dos pesos"73 y "Otro biombo de China, negro y dorado, de dos varas y tres cuartas de alto, de doce tablas, en doscientos pesos". ${ }^{74}$

En Europa no había ninguna producción parecida a la laca antes del siglo xvi, por lo que el uso del término pintura para referirse al maque en esa época sugiere la dificultad de nombrar obras de técnica desconocida y, a la vez, la pervivencia de concepciones pictóricas de origen medieval, que admitían gran cantidad de materiales y soportes. Quizá pueda decirse lo mismo del término

7I. Según Palomino, "La quarta y última especie de pintura embutida es la plastica: Esta pinta con pasta de yeso, secretamente preparada, adjuntas las colores que conducen a la representacion. De esto hay también poco, aunque en nuestros tiempos, y en esta corte, se hacen bufetes de esta pasta, con harto primor, imitando frutas, flores, páxaros, y otras cosas; y lo que mas admira es el pulimento que admite, como si fuera un xaspe [...] formando los senos de lo que se ha de executar en la pasta del tablero principal, se van introduciendo en ellos pastas de diferentes colores segun lo pide la pintura". El autor ańade "En el reino de Méjico usan los indios este género de pintura embutida, para pintar las canoas, aljofainas, y otras vasijas, y alhajas de madera, cubriéndolas con una pasta de aquel color, de que quieren que sea el campo de la pintura; y quedando esto bien pulido, y en moderada cantidad, para que no salte, van dibujando lo que han de pintar; y vaciándolo con un punzón, y paletilla de hierro, van rellenando aquel vacío del color más general de la figura; y entresacando después las demás partes, que constan de otra, y de otras tintas, lo van rellenando de ellas, hasta que estando en su perfección, lo pulen, y barnizan con barnices muy fuertes, que hacen de varias frutas, gomas y gusanos de ciertos árboles, y queda a manera de charol, con gran lustre, y fortaleza”, en El museo pictórico y escala óptica, 2 vols. (Madrid: Aguilar Maior, 1988 [ $\mathrm{I}^{\mathrm{a}}$ edición, I715]), I30-I3I.

72. AGN, Notaría I33, Juan José Cruz y Aguilar, "Recibo dotal de don Francisco de Villegas (I730)", vol. 836, f. I8.

73. AGN, Vinculos y Mayorazgos, "Testamentaria de don Pedro Chavarría. Guanajuato (I747)", vol. 22, exp. 3, f. 5 .

74. Curiel, "Los biombos novohispanos", 29, la referencia es de 1747. 
barniz en la Nueva España, cuyo uso en relación con los maques fue mucho más común en el siglo XVI.

El empleo común de estos términos sugiere que se advirtieron distintos grados de relación entre las obras. La información documental, así como las definiciones del diccionario, sugieren que dicho vínculo obedece, hasta cierto punto, al hecho de que algunas obras europeas, así como virreinales, tomaron como modelo las asiáticas. Básandonos en la terminología de la época, aquí se emplearán indistintamente los términos maque y laca para referirnos tanto a las obras asiáticas, como a las europeas y novohispanas.

\section{Las obras y sus técnicas 75}

Las lacas extremo-orientales se hacen con la resina de los árboles Toxicodendron vernicifluum (antes Rhus vernicifluum), nativos de Asia. La materia prima es una savia lechosa (llamada urushi en Japón) usada para recubrir madera, bambú, textiles, cuero, metal o cualquier material ligero; ${ }^{76}$ una vez recolectada mediante cortes a los árboles, se agita, calienta, filtra y almacena para su uso posterior. La sustancia, viscosa y transparente, se endurece como resultado de una compleja reacción química interna, que requiere de una humedad alta. El material se polimeriza y dota a los objetos de extraordinaria dureza y resistencia al agua, los ácidos, los golpes y el calor, ${ }^{77}$ pero es vulnerable a la exposición prolongada y directa a la luz del sol. ${ }^{78} \mathrm{Su}$ cualidad más importante es que puede pulirse hasta alcanzar un brillo notable. $\mathrm{Al}$ ser viscoso y pegajoso, puede contener incrustaciones o incluso grandes fragmentos de otros materiales. ${ }^{79} \mathrm{El} \mathrm{minu-}$ cioso proceso de elaboración implica muchos pasos, a menudo realizados por distintas personas; la fabricación de las piezas más finas puede tardar años.

75. Estas descripciones se basan en estudios que han abordado de manera general la técnica de las obras. La información puede no corresponder a algunos ejemplares, pero ofrece una visión representativa de los procedimientos empleados.

76. Oliver Impey y Christiaan Jörg, Japanese Export Lacquer I580-I850 (Ámsterdam: Hotei Publishing, 2005), 75 .

77. Véase www.bishopmuseum.org/research/pdf/cnsv-lacquer.pdf, consultado el I8 de marzo de 2016.

78. Véase "Urushi Lacquer. The Shining Beauty of Japan", consultado el 20 de febrero de 20r6, en www.kyotoguide.com/ver2/thismonth/urushi.html.

79. Impey y Jörg, Japanese Export Lacquer, 75-76. 
La durabilidad depende de la estabilidad del objeto al que se aplica la laca. ${ }^{80}$ Ésta es esparcida en estado líquido con pincel, en capas muy finas; después de cada capa, la obra se guarda en un ambiente húmedo y libre de polvo por al menos un día; más tarde se pule y se aplica otra capa. El objeto resultante puede tener desde unas cuantas hasta más de un centenar de capas, aunque las obras que circularon en la Nueva España probablemente hayan tenido pocas. ${ }^{81}$ La laca puede usarse en estado transparente, o puede ser opaca y de color si se le añaden pigmentos minerales. En la época la paleta era limitada. Para las lacas rojas y negras se usaban cinabrio y óxido de hierro, mientras que para las amarillas se usaba oropimente. ${ }^{82}$

En la segunda mitad del siglo xvi y hasta $1630,{ }^{83}$ la presencia portuguesa en el sur de Japón dio lugar a producciones artísticas hoy conocidas como namban; ${ }^{84}$ muchas lacas namban se exportaron, aunque también hubo una producción para el consumo interno. Estas obras corresponden al periodo Momoyama (I573-1615), cuyas lacas exhiben fondos negros poblados por figuras abigarradas: especies nativas de flores de otoño, aves y racimos de uvas, así como motivos geométricos. Las figuras se delinean con oro o plata, con ocasionales detalles de color. ${ }^{85}$

Las lacas namban incluyen objetos de uso católico, tales como atriles, hostiarios y trípticos y se distinguen por sus figuras embutidas de concha - inicialmente, madreperla de las especies Turbo o Trochus, pero después se usó la Haliotis, de color más fuerte. Como la madreperla es gruesa, la laca asociada a ella también lo era. Se aplicaba con un pincel grueso y probablemente las capas

80. Impey y Jörg, Japanese Export Lacquer, 75-76.

8I. Ordóñez Goded, "De lacas y charoles", 46.

82. "Urushi Lacquer".

83. Los primeros contactos entre Portugal y Japón datan de I543. No hay acuerdo respecto a la fecha exacta en la que empezaron a hacerse obras adaptadas a las demandas europeas, pero es lógico suponer que esto ocurrió tan pronto como los misioneros católicos (principalmente jesuitas) iniciaron su actividad en Japón, en I549. Para una revisión historiográfica sobre dicha actividad y su impacto en el ámbito artístico, véase Noriko Kotani, "The Historiography of Jesuit Art in Japan: Inside and Outside Japan”, consultado el is de octubre de 20I6, en http://itatti.harvard.edu/sites/ default/files/\%5Bvsite\%3Asitepurl\%5D/files/kotani_jesuit_art_in_japan_final.pdf?m=I43763963I.

84. El término namban significa "bárbaros del sur" y los japoneses lo usaron para referirse a los extranjeros a mediados del siglo xvi. Sobre la historiografía del término en relación con el arte, véase Ordóńez Goded, "De lacas y charoles", 43, n. 50.

85. Impey y Jörg, Japanese Export Lacquer, 75. La técnica también se describe en Maria Helena Mendes Pinto, Lacas namban em Portugal (Lisboa: Inapa, 1990), 45-47. 
no se pulían mucho. La pintura de oro se aplicaba sobre el fondo, así como sobre los embutidos de concha. ${ }^{86}$

En las lacas del periodo Edo (1603-1868) predominan los fondos negros y las composiciones suelen exhibir paisajes - en ocasiones contenidos en una cartela polilobulada. Se usa la técnica makie, que consiste en poner polvo de oro y plata sobre la laca húmeda, que se adhiere y hunde ligeramente en la superficie. Después se pule, se cubre con laca transparente y se vuelve a pulir. El makie podía pulirse para quedar plano (togidashi), o bien formar un bajorrelieve (hiramakie) o altorrelieve (takamakie). ${ }^{87}$

En I638, Japón cerró sus fronteras, dejando sendos puertos abiertos al comercio con China y Holanda. Las obras enviadas a Europa fueron exclusivamente de uso civil. La rivalidad entre Espańa y Holanda no favoreció el comercio regular; sin embargo, en la Nueva España siguieron circulando obras japonesas, probablemente llegadas a través de China ${ }^{88}$ Respecto a la circulación novohispana de lacas del periodo Edo, cabe mencionar el púlpito de la iglesia de San José del Milagro de Tlaxcala, formado con paneles de aquéllas. ${ }^{89}$ Al parecer, la obra data de $1708 .^{90}$

Entre las lacas chinas exportadas a Occidente destacan, a partir de finales del siglo XVII, los biombos de Coromandel (fig. 2), ${ }^{91}$ que suelen tener I2 hojas y 2.5-3 metros de altura ${ }^{92}$ y se caracterizan por sus fondos negros poblados por figuras multicolores talladas y pintadas. Se trata de escenas palaciegas, dioses

86. Impey y Jörg, Japanese Export Lacquer, 75-76.

87. Impey y Jörg, Japanese Export Lacquer, 76.

88. El tema aún se está investigando. Sin embargo, se han descubierto numerosos vestigios arqueológicos de cerámica japonesa de esa época en México. Nogami Takenori, "Ceramic Trade Network Around Taiwan Straits and the Galleon Trade", en The Ist World Congress of Taiwan Studies, 20I2, consultado el 3 de agosto de 20I6, en http://wcts.sinica.edu.tw/wctsI/paper/c4p3paper.pdf.

89. Sofía Sanabrais, "The Biombo or Folding Screen in Colonial Mexico", Asia and Spanish America, 8I.

90. Sanabrais, “The Biombo", 8r. La fecha la registró por primera vez José Rojas Garcidueñas, "San Miguel del Milagro", Anales del Instituto de Investigaciones Estéticas, núm. 4 (I939): 30, consultado el 30 de agosto de 20I6, en http://dx.doi.org/Io.2220I/iie.I8703062e.1939.4.I66, p. 30. Sin embargo, el autor se refirió a la fecha del púlpito de tecali, no respecto a la fecha en la que los paneles del biombo se habían colocado en aquél.

9I. La costa de Coromandel se encuentra al sureste de la India, y su uso en relación con esta producción china se debe a que desde ahí se vendían a Europa. Wilfried de Kesel y Greet Dhont, Coromandel Lacquer Screens (Gante: Art Media Resources Ltd., 2002) 9.

92. En el siglo XviII se hicieron ocasionalmente ejemplares de 6, 8 y io paneles. De Kesel y Dhont, Coromandel, iI. 


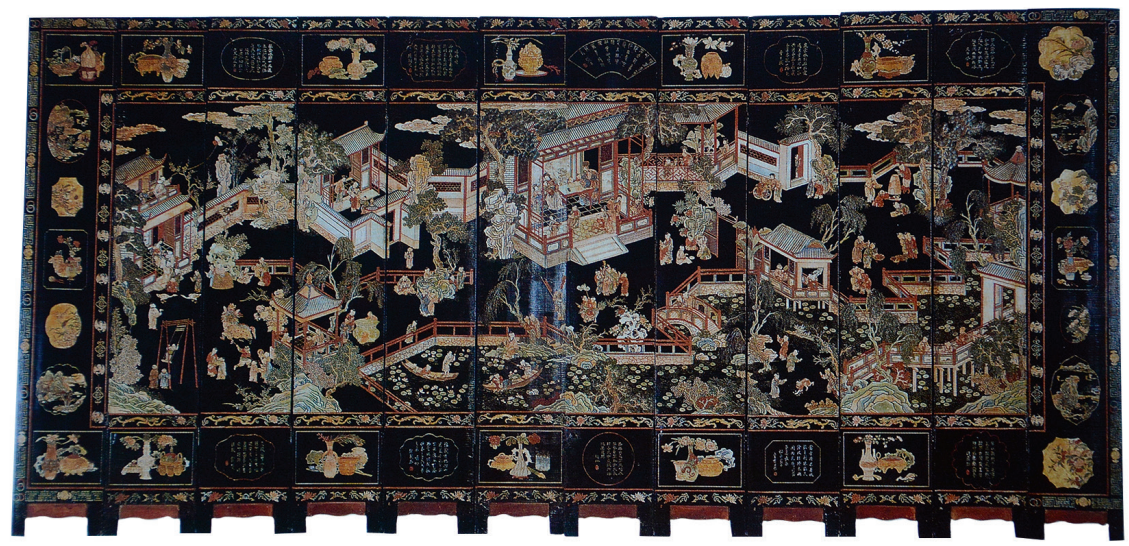

2. Biombo de laca de I2 hojas de Coromandel, China, periodo Kangxi, $2.73 \times 5.64$ m. Colección particular. Imagen tomada de De Kesel y Dhont, Coromandel Lacquer Screens (vid supra n. 9I), 54.

taoistas, paisajes, escenas de montería y motivos de flores y pájaros, bordeados por anchas franjas de flores e inscripciones budistas y taoistas. ${ }^{93}$ La producción era doméstica; surgió en el siglo xvi y solía usarse como regalo de cumpleaños para personajes distinguidos o para señalar la jubilación o promoción de oficiales de alto rango. ${ }^{94}$

En su fabricación se usa tabla (a menudo de pino), pintura y barniz. La tabla se cubre con una imprimatura al parecer consistente en sangre de cerdo, laca en bruto y cenizas. Tras un pulido cuidadoso, se recubre con numerosas capas de laca café o negra. Una vez que la laca endurece, las figuras ornamentales se cortan en relieve, hasta la capa base. Las incisiones se pintan con empastes de colores o con polvo de oro mezclado con cola, de modo que el colorido diseño resultante sobresale del fondo oscuro. ${ }^{95}$

A mediados del siglo XVII, en Europa se desarrollaron muchas recetas para imitar las lacas asiáticas. Destacan las del sacerdote jesuita Martino Martini, publicadas en el Novus Atlas Sinensis en Ámsterdam (1655); las de Louis le Comte, publicadas en Nouveaux Mémoires sur l'état présent de la Chine (1696) y las de Filippo Bonanni, publicadas en el famoso Trattato sopra la vernice

93. Kopplin, "Lacquerware in Asia”, 39.

94. De Kesel y Dhont, Coromandel Lacquer Screens, 22.

95. Kopplin, "Lacquerware in Asia", 39. 


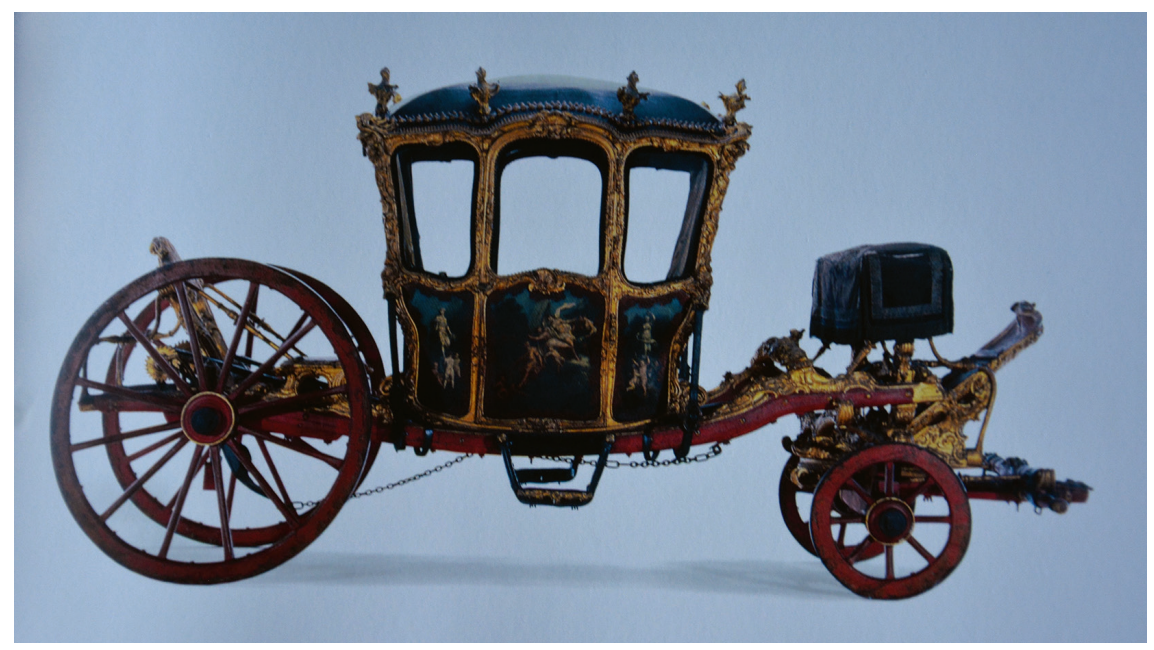

3. Berlina de vernis Martin, París, ca. I760, $2.26 \times 5.90 \times 2.97$ m. Museu Nacional des Coches, Lisboa. Imagen tomada de Forray-Carlier y Kopplin, Les Secrets de la laque française (vid infra n. IOI), I95.

detta communemente cinese (1709 y 1720). ${ }^{96}$ Esta obra fue la más exhaustiva de la época; circuló ampliamente en Europa y se tradujo al francés y al holandés. Bonanni sabía que las lacas asiáticas no podrían producirse en Europa y divulgó muchas recetas para imitarla. ${ }^{97}$

Estas recetas y sus variaciones posteriores, así como los reportes de viaje ricamente ilustrados y las obras importadas desde China y Japón, indujeron una oleada de imitaciones europeas a finales del siglo XVII. ${ }^{98}$ Destacan las francesas, inglesas, alemanas e italianas; sus variantes técnicas son tan numerosas, que es imposible mencionarlas todas. Algunas técnicas inglesas se conocen como japanning (figs. IIa, IIb y I4), mientras que entre las francesas la más importante fue el vernis Martin (fig. 3) y entre las italianas, la lacca povera (fig. 4). En Alemania Gérard Dagly y — hasta cierto punto- Martin Schnell se especializaron en imitar las lacas japonesas. Las lacas europeas se basan en el uso de resinas, como el copal americano y el ámbar. Aunque todas las téc-

96. Kopplin, "Lacquerware in Asia", 45.

97. Kopplin, "Lacquerware in Asia", 45.

98. Kopplin, "Lacquerware in Asia", 45. 


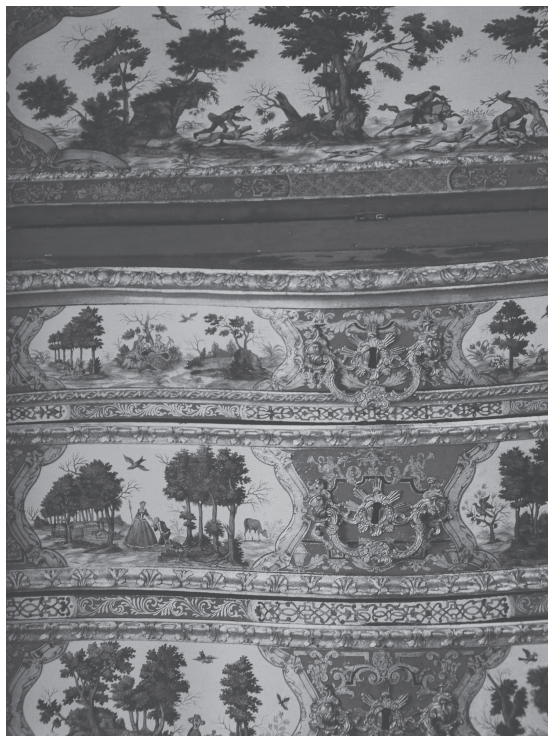

4. Detalle de una cómoda-escritorio con el escudo de armas del papa Pío VI (adición posterior), lacca povera, principios del siglo XVIII, $277 \times 147 \times 77.5 \mathrm{~cm}$. Colección particular, Roma. Imagen tomada de Kopplin, European Lacquer (vid infra n. Ioo), 27.

nicas se usaron, en ocasiones, para imitar las lacas asiáticas, no necesariamente se consideraron inferiores, pues en ocasiones alcanzaron un alto grado de sofisticación y lujo.

El japanning inglés se popularizó desde finales del siglo xviI. Para fabricarlo se emplearon madera, cuero, resinas naturales, alcohol, aceites, pigmentos y polvo u hoja de metales. La estructura consistía en una base - la más común era la madera- que se cubría con barniz y capas de decoración. En el siglo XVIII, se usaron como barnices las resinas naturales disueltas en aceite, lo que las hacía más duraderas y resistentes. ${ }^{99}$ Las lacas inglesas se distinguen por los fondos polícromos, aunque el japanning tiende a preferir los negros y rojos. Los diseños se alejan de los japoneses; la densa decoración sugiere cierto horror vacui e incluye secciones en relieve. Las escenas tienden a disponerse de modo curvilíneo, en patrones geométricos. ${ }^{100}$

99. Katja Tovar Azuero, "The Development of English Black Japanning I620-I820", Conservation Journal, núm. 52 (primavera, 2006), consultado el 28 de marzo de 20I6, en www.vam.ac.uk/content/ journals/conservation-journal/issue-52/the-development-of-english-black-japanning-1620-1820/.

Ioo. Kopplin, European Lacquer. Selected Works from the Museum für Lackkunst Mairister (Múnich: Hirmer Verlag, 2010), 69. 
El vernis Martin emplea un barniz blanco de copal que produce una laca ligera y en extremo transparente, dura, uniformemente lisa y durable. Este barniz no sólo se usó en distintos tipos de muebles, sino también en coches, pues permitía la apariencia de refinamiento y lujo que los consumidores buscaban en esas obras. La manufactura de coches involucró a distintos especialistas; el lacado correspondía al pintor barnizador. ${ }^{\mathrm{IOI}} \mathrm{Al}$ parecer, el trabajo más codiciado se hacía con aventurina, para imitar los admirados fondos japoneses nashiji, salpicados de oro de apariencia granulada, cuyo brillo era dorado rojizo. ${ }^{102}$ Como se verá, en la Nueva España se hicieron coches de laca; aunque se ignora la técnica empleada, no hay duda de su parecido con las europeas.

En España Felipe V e Isabel de Farnesio mostraron gran interés por las lacas. ${ }^{103}$ En I716, la reina contrató al arquitecto René Carlier, que adornó la pieza de las Furias del Alcázar con fragmentos de biombos chinos, ${ }^{\mathrm{IO} 4}$ siguiendo una moda popularizada en los ámbitos cortesanos y burgueses de Alemania, Inglaterra, Francia, Holanda e Italia. En I735, el rey trajo a Madrid al famoso arquitecto Filippo Juvarra a quien encargó, entre otros trabajos, la decoración de su dormitorio. El programa de Juvarrra se basó en paneles de laca asiáticos y espejos, ${ }^{105}$ aunque también se hicieron ex profeso otras lacas para el dormitorio, así como para la habitación de los espejos. ${ }^{106}$

Para entonces ya había oficiales charolistas en la villa de San Ildefonso; su continua actividad fue impulsada por el desabasto de lacas asiáticas. ${ }^{107}$ Según

IoI. Anne Forray-Carlier y Monika Kopplin, Les Secrets de la laque française: le vernis Martin (París: Les Arts Décoratifs, 20I4), I84. En I732, Guillaume Martin anunciaba en el Mercure de France que "también se compromete a hacer carruajes en el hermoso esmalte de aventurina, a hacer la pintura y dorado, y garantiza el dorado de los estragos del tiempo", Les Secrets de la laque française, 185.

I02. Kopplin, European Lacquer, II8.

I03. Aunque los Habsburgo se habían interesado por las obras desde el siglo Xvi, fue en el siglo XVIII cuando la producción española alcanzó mayor desarrollo, tanto en la corte como en ámbitos burgueses. Ordóńez Goded, "De lacas y charoles", 380-427.

I04. Teresa Lavalle Cobo, "El coleccionismo oriental de Isabel de Farnesio", en Oriente en Palacio (Madrid: Patrimonio Nacional, 2003), 2II.

I05. García Fernández, "Les Panneaux en laque de la chambre de Philippe V au palais de La Granja de San Ildefonso", en Philippe V d'Espagne et l'art de son temps. Acts du Colloque des 7, 8 et 9 juin 1993 á Sceaux, V. II (Domaine de Sceaux: Musée de l'Ile-de-France, I995), 194.

I06. García Fernández, "Les Panneaux en laque”, i99.

I07. En agosto de I734 Francisco de Varas había "estado buscando biombos de charol en Cádiz por encargo de la reina y al no haberlos encontrado en esta ciudad, recomienda a un artesano que trabaja 'pulidamente el charol', enviando de muestra dos pequeńas tablas en un cajoncito", en García Fernández, "Les Panneaux en laque”, 198. 
las memorias de los gastos de la Furriera de 1736, Juvarra empleó: "una libra de aceite común para poner los colores y barnices y seis arrobas de vino tinto para hazer espíritu para el varniz de los charoles". ${ }^{108}$ Los ingredientes parecen corresponder a la receta del padre Jannard (I667), que "recomendaba coger goma laca muy pura, meterla en un vaso de cristal, cubrirla con cinco dedos de 'espíritu de vino', después taparla y ponerla al sol durante tres o cuatro días, agitando de vez en cuando. Cuando estuviera suelta, se debía pasar a una tela y se dejaba reposar durante un tiempo". ${ }^{\circ 99} \mathrm{Al}$ parecer en la Nueva España no hubo charolistas, pero sí carroceros que, en ocasiones, incursionaron en el trabajo del maque, ${ }^{\text {IIO }}$ con técnicas que aún se desconocen.

Por otro lado, el interés por las lacas podría haber llevado a algunos novohispanos a experimentar con las recetas europeas. Las producciones domésticas tuvieron gran difusión en Inglaterra, donde Robert Sayer publicó sendas ediciones (1758 y 1762) de The Ladies Amusement; or, Whole Art of Japanning Made Easy. ${ }^{\text {III }}$ El libro, ricamente ilustrado, explicaba la técnica de découpage o lacca povera que usa papel recortado y que fue popular en buena parte de Europa, ${ }^{\text {II2 }}$ sobre todo entre mujeres jóvenes de clase alta, aficionadas a este tipo de trabajo desde finales del siglo XVII. ${ }^{\mathrm{II}}{ }^{2}$

Acaso en la Nueva España se hayan conocido recetas europeas de laca para aficionados. En 1980, Xavier Moyssén publicó el manuscrito "Secretos de lacas, charoles y colores", que al final incluía, con otro tipo de letra, el nombre y firma de Antonia Rigo de Baver, "residente al parecer, de la Ciudad de México". ${ }^{\text {II }}$ El texto se halló en una colección mexicana, dentro de un ejemplar de Don Quijote de la Mancha impreso en México en 1833; al parecer la familia lo había conservado desde el siglo XIX. ${ }^{\mathrm{II}}$

I08. Valeria Ferrozzi y Marina Cremona, I mobili d'antiquariato. Antiche tecniche di decorazione, moderni metodi di restauro, Storia dell'Arte. Testi e Manuali (Bolonia: Zanichelli, 1989), I8.

I09. García Fernández, "Les Panneaux en laque”, 199.

IIO. El tema se discute en las páginas I74 a I77.

III. Danielle O. Kisluk-Grosheide, "A Japanned Cabinet in The Metropolitan Museum of Art”, Metropolitan Museum Journal, núms. 19/20 (1986): 88.

II2. Kopplin, European Lacquer, 67.

II3. Kisluk-Grosheide, "A Japanned Cabinet”, 88.

II4. Xavier Moyssén, pról., Secretos de maques, y charoles, y colores (México: Instituto Nacional de Antropología e Historia-Dirección de Restauración del Patrimonio Cultural/Secretaría de Educación Pública, 1980), XV.

II5. Moyssén, Secretos de maques, XV. 
La obra está fechada en I755 y supuestamente traducida del francés por Francisco Vicente Orellana. ${ }^{116}$ En realidad corresponde al Tratado de barnizes y charoles de Bonanni, que circuló en España en dos versiones impresas. Ambas son valencianas; la primera está firmada — plagiada — en 1735 por Genaro Cantelli; la segunda es la de Orellana, que reproduce el mismo texto aunque ampliado con otro tratado y noticias. ${ }^{I 17} \mathrm{La}$ importancia de la probable circulación local de esta obra reside en que estos manuales se dirigían a un público amplio y favorecieron la elaboración de lacas que, en ocasiones, pretendían imitar las chinas o japonesas explícitamente.

\section{Los objetos y la información documental}

Una parte de este estudio se basa en el análisis de las referencias documentales a 226 objetos de maque, procedentes de 53 inventarios de bienes del siglo XVIII, así como de las menciones a otros II2 objetos — procedentes de 26 documentos- que omiten el término maque, pero cuyas descripciones sugieren que se trata de lacas (véase tablas i y 2). De los 79 documentos, 27 son inéditos, localizados en el Archivo General de la Nación, el Archivo General de Notarías y el Archivo de Notarías de Puebla. El resto de las referencias se han publicado en distintas fuentes. ${ }^{\text {II8 }}$

En su artículo sobre los objetos que los inventarios de los Medici y austrohúngaros llaman "indios", Jessica Keating y Lia Markey han planteado algunos problemas pertinentes en relación con nuestro análisis. Si bien los documentos pueden contener información valiosa respecto al tipo de objeto, paleta,

II6. Moyssén, Secretos de maques, XV.

I17. Cristina García Martínez, "El Salón Gasparini: entre chinerías y rocallas", en Las artes de un espacio y un tiempo: el setecientos borbónico, María del Mar Albero Muñoz y Manuel Pérez Sánchez, eds. (Madrid: Fundación Universitaria Española, 2015), 688 y Guadalupe Carramiñana Pellejero, "Historia de los barnices para instrumentos musicales de cuerda frotada. Estado del arte y reflexiones", tesis de maestría en Ciencia y Restauración del Patrimonio Histórico-Artístico (Universidad Politécnica de Valencia, 20II), I8.

II8. Vargaslugo y Curiel, Juan Correa... III; El mobiliario en Puebla; Eugenio del Hoyo, Plateros, plata y alhajas de Zacatecas (I568-I782) (Gobierno del Estado de Zacatecas-Instituto de Cultura de Zacatecas, I986); Curiel, "Los biombos"; "Al remedo de la China"; "El efímero"; "Cuatro inventarios" y Romero de Terreros, Una casa del siglo XVIII. Puesto que se trata de fuentes secundarias, en muchos casos no es posible saber el origen social de los personajes estudiados, la ciudad en que murieron, y otros datos relevantes. 
material, tamańo, calidad y origen, sus respuestas son siempre fragmentarias pues las meras descripciones nunca bastan para reconstruir las obras. ${ }^{\text {I9 }}$ La confiabilidad de la información varía mucho, dependiendo de quién valúa y describe los bienes. Incluso la manera de nombrar los objetos cambia en distintos documentos. ${ }^{120}$ A menudo los tasadores no comprenden a profundidad las obras y la misma fuente puede en ocasiones identificar bien unos objetos y clasificar mal otros. ${ }^{\text {I2I }}$ Además, la riqueza de algunos ejemplares apenas es sugerida por su precio. ${ }^{\mathrm{I22}}$

\begin{tabular}{|c|c|c|c|c|}
\hline $\begin{array}{c}\text { Descripción } \\
\text { de la obra }\end{array}$ & $\begin{array}{c}\text { Menciones } \\
\text { documentales }\end{array}$ & $\begin{array}{l}\text { Número } \\
\text { de objetos }\end{array}$ & Fechas & Rango de precios \\
\hline Maque & 50 & 163 & I703 - I747 & $\begin{array}{c}\text { I peso } 4 \text { reales - } 500 \\
\text { pesos }\end{array}$ \\
\hline Maque fingido & 6 & 6 & I7IO - I734 & IO -8 o pesos \\
\hline Maque chino & 30 & 42 & $1704-1784$ & I2 reales - 500 pesos \\
\hline Maque japonés & 2 & 4 & I7O4 & $80-300$ pesos \\
\hline $\begin{array}{l}\text { Maque de } \\
\text { Michoacán }\end{array}$ & 3 & 3 & 1708 & 25 pesos \\
\hline Maque achinado & 3 & 8 & Sin información & Sin información \\
\hline
\end{tabular}

Tabla I. Objetos de maque e información documental

\begin{tabular}{|c|c|c|c|c|}
\hline $\begin{array}{c}\text { Descripción } \\
\text { de la obra }\end{array}$ & $\begin{array}{c}\text { Menciones } \\
\text { documentales }\end{array}$ & $\begin{array}{c}\text { Número de } \\
\text { objetos }\end{array}$ & Fechas & Rango de precios \\
\cline { 1 - 3 } De Michoacán & I4 & 43 & I708 - I747 & I - 20 pesos \\
\cline { 1 - 2 } De China & IO & 42 & I7IO - I747 & IOO - 200 pesos \\
\cline { 1 - 2 } Achinado & II & 23 & I7I6 - I786 & 3 - 40 pesos \\
\cline { 1 - 2 } Encarnado & 4 & 4 & I724 - I784 & IO - 40 pesos \\
\hline
\end{tabular}

Tabla 2. Objetos sin referencia explícita pero que se presume son de maque

II9. Keating y Markey, “Indian’ Objects”, I4.

I20. Keating y Markey, “Indian' Objects”, I5.

I2I. Keating y Markey, “Indian' Objects”, I3.

I22. Keating y Markey, “Indian' Objects”, I4. 
Estas consideraciones son relevantes pues numerosos documentos aquí revisados se refieren a obras perdidas, en ocasiones de exportación. Al parecer, a menudo se trata de objetos hechos sobre pedido que podían involucrar a talleres de diferentes lugares. Con todo, el análisis conjunto de la información documental y de algunas obras conservadas permite sugerir posibilidades aún no exploradas en el estudio de este tema. Para profundizar en el alcance de las lacas asiáticas en la Nueva España es necesario hacer estudios técnicos que consideren la existencia de distintos tipos de maque - y técnicas pictóricas que los remedan. Las lacas achinadas involucraron una variedad de técnicas y centros productores que apenas empiezan a vislumbrarse.

\section{¿De dónde era el maque chino?}

De las 226 menciones documentales a objetos de maque localizadas, 77 omiten tanto los orígenes como las descripciones. ${ }^{\mathrm{I} 23}$ En 98 casos la obra se describe sin mencionar su origen, mientras que en otros 39 se proporcionan ambos datos. En cinco casos el origen de la obra se menciona, pero ésta no se describe, mientras que en siete más, la obra ni se describe ni se menciona su origen. Así pues, es muy difícil plantear hipótesis sobre la procedencia de cerca de 80 por ciento de las obras registradas en los documentos.

Ahora bien, el problema rebasa la mera procedencia. Las referencias documentales al maque chino exceden notablemente a las de otros orígenes, pues se encontraron 37 y sólo cuatro a obras japonesas y tres a maques michoacanos. Sin duda, muchas de las obras que los documentos llaman chinas lo fueron. Sin embargo, en la Nueva España el término "chino" también se usó para designar un territorio enorme y diverso y el "maque chino" se asoció a objetos dispares (mesas, sillas, biombos, cajas, atriles) que, como se verá, se hicieron tanto en China, como en Japón y en otras partes de Asia, además de Europa.

Aunque la identificación de los orígenes de las obras es desde luego deseable, el interés de este estudio trasciende dicha identificación. Muchas obras

I23. La falta de precisión sobre el origen de los objetos no es exclusiva de la Nueva España. Véase María Paz Aguiló Alonso, "El coleccionismo de objetos procedentes de ultramar a través de los inventarios de los siglos XVI y XVII", en Relaciones artísticas entre España y América (Madrid: Consejo Superior de Investigaciones Científicas-Centro de Estudios Históricos-Departamento de Historia del Arte Diego Velázquez, I990), I07-I49, así como Impey y Jörg, Japanese Export Lacquer, 283 y 285. 
fusionaron el trabajo, materiales y estética de dos o más culturas; ${ }^{124}$ sus características se modificaron constantemente, al servicio de los cambiantes intereses de los consumidores. Un solo término, ya sea chino o achinado, no alcanza para nombrar muebles cuya elaboración puede abarcar, por ejemplo, el uso de materiales europeos y diseños japoneses, reinterpretados en Filipinas con distintos materiales y técnicas. ${ }^{125}$ De ahí que el intento de identificar los orígenes precisos de las obras descritas en los documentos a menudo se encuentre más allá de nuestro alcance.

Por ejemplo, un documento zacatecano de I7Io menciona "Un escritorillo, de doce gavetas, de maque negro, laboreado de oro, de China, embutido en concha nácar, coral y hueso, hechura exquisita, con cantoneras y cerradura de plata". ${ }^{226}$ La obra se tasó en 600 pesos. La minuciosa descripción, así como la referencia a la "hechura exquisita" permiten afirmar la altísima calidad de la obra. Además, se trata de la segunda más cara aquí registrada —el precio excede el de algunos biombos "chinos" de hasta 24 tablas registrados en documentos de mediados del siglo xviII, comentados más adelante.

Según el investigador Eugenio del Hoyo, el escritorillo procede del inventario de bienes de María Correa de Silva, cuya familia había poseído un gran patrimonio en el siglo XVII, que se hallaba muy mermado a principios del XVIII. ${ }^{127}$ Acaso la obra date de décadas atrás. En principio, muchas lacas "chinas" negras podrían haber sido japonesas, pues tal color predominó tanto en la época Momoyama como en la Edo. Además, en el mercado internacional las lacas japonesas de buena calidad eran particularmente caras y esta descripción sugiere que el precio se determinó por la excepcional calidad del trabajo y no sólo por su origen.

La referencia al maque negro, trabajado en oro y embutido de concha nácar recuerda las lacas namban (fig. 5). ${ }^{\mathrm{I} 2}$ Ahora bien, ni el coral ni el hueso son frecuentes en dichas lacas. Sin embargo, esta producción se desarrolló para satis-

I24. Keating y Markey, “Indian' Objects”, II, n. 6. Curiel ha advertido otros aspectos de este fenómeno, a partir de los marfiles, "Perception of the Other", 26.

125. Estas reflexiones se basan en Maria da Conceição Borges de Sousa, "Foreword", Voyages, 3.

I26. Del Hoyo, Plateros, plata y alhajas, II9.

I27. Del Hoyo, Plateros, plata y alhajas, II9.

I28. Sobre la circulación del arte namban en la Nueva España, véase Sofía Sanabrais, "From Byobu to Biombo: The Transformation of the Japanese Folding Screen in Colonial Mexico", en Daniela Bleichmar y Meredith Martin, eds., Art History Special Issue: Objects in Motion in the Early Modern World 38, núm. 4 (septiembre, 2015): 778-791 y Alexandra Curvelo, "The Artistic Circulation Between Japan, China And The New-Spain in The I6th-17th Centuries", Bulletin of Portuguese-Japanese Studies, I6 (junio, 2008): 59-69. 


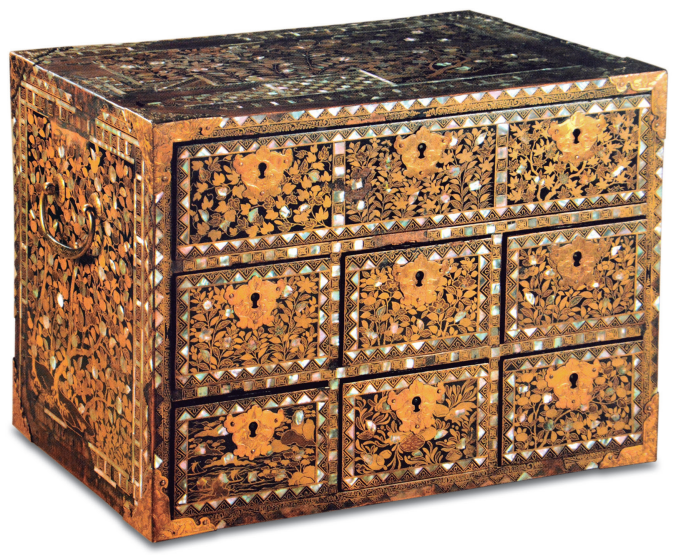

5. Escritorio de laca namban, Japón, $1580-1600,31 \times 42.5 \times 29 \mathrm{~cm}$. Castillo de Ambras. Imagen tomada de Impey y Jörg, Japanese Export Lacquer (vid supra n. 76), I2O.

facer las demandas europeas. Los portugueses buscaron versiones "exóticas" de formas familiares que pudieran venderse en Europa y Asia ${ }^{\mathrm{I} 29}$ y algunos ejemplares namban de gran calidad exhiben características particulares. ${ }^{130}$ Así, en la pieza zacatecana el uso de coral y hueso (así como la hechura exquisita) bien podrían deberse a algún encargo específico. ${ }^{\mathrm{I} I}$

Las lacas namban se inspiraron, en parte, en las lacas indoportuguesas de fondos negros poblados de incrustaciones de nácar, perlas y piedras preciosas de Gujarat (fig. 6), surgidas a principios del siglo XVI, con el establecimiento de los portugueses en la zona. Estas obras se hicieron con goma laca de origen animal. ${ }^{132}$ Algunos ejemplares permanecen en prominentes colecciones españolas, como el monasterio de las Descalzas Reales; ${ }^{133}$ hasta ahora se ignora si circularon en la Nueva Espańa, pero la descripción de la obra zacatecana sugiere dicha posibilidad.

Por otro lado, es poco probable que la obra haya sido china. La técnica de los biombos de Coromandel se usó en vitrinas y cajas, ${ }^{134}$ pero las obras son

I29. Impey y Jörg, Japanese Export Lacquer, II.

I30. Impey y Jörg, Japanese Export Lacquer, 85-96.

I3I. Al parecer, en las producciones dedicadas al mercado europeo estos fenómenos fueron especialmente notables en los siglos XVI y XVII. Este tipo de encargos están documentados en el caso de la porcelana y es posible que también hayan ocurrido en el caso de las lacas. Robert Finley, The Pilgrim Art: Cultures of Porcelain in World History (California World History Library, 2010), I42. I32. José Carlos Frade y Ulrich Körber, "Asian Lacquers. A Crossroads Between India And The Ryukyu Islands", en Voyages. Namban and Other Lacquers (Lisboa: Museu Nacional de Arte Antiga, 20II), IO.

I33. Ana García Sanz, "Relicarios de Oriente", Oriente en Palacio, I30.

134. Kopplin, "Lacquerware in Asia", 39. 
6. Arqueta indoportuguesa de laca, Gujarat, mediados del siglo Xvi, $40 \times 55 \times 32 \mathrm{~cm}$. Monasterio de las Descalzas Reales, Madrid. Imagen tomada de Oriente en Palacio (vid supra n. I04), I35.

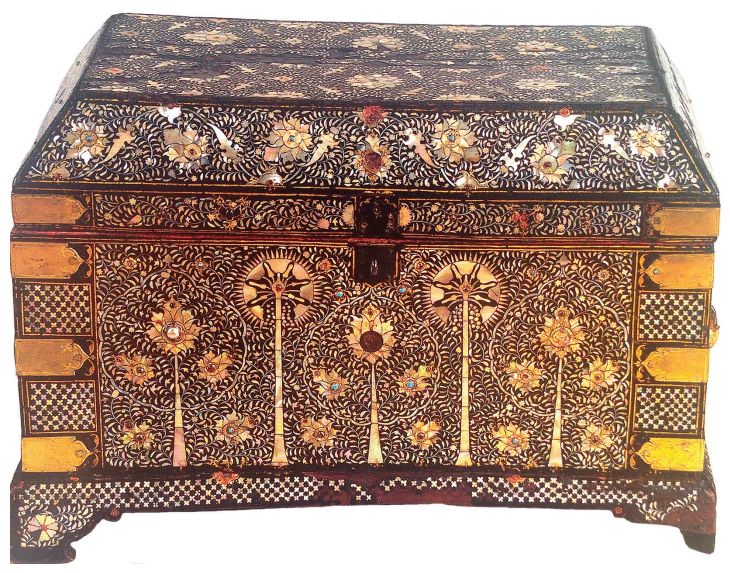

policromadas y no incluyen la incrustación de materiales — de hecho, surgieron como una alternativa menos costosa al trabajo de incrustación. ${ }^{135}$ No obstante, hace falta profundizar en los intercambios comerciales que hubo en Manila para satisfacer las demandas de los mercados hispanoamericanos. Así como en Asia y Europa se desarrollaron estrategias para expandir los mercados europeos, podría haber habido otras orientadas a los virreinales, cuya importancia económica apenas empieza a apreciarse en su justa medida. ${ }^{{ }^{36}}$ Así pues, quizá se trate de una obra china o filipina hecha sobre pedido.

Igualmente engañosos resultan los orígenes de "Otro biombo de China, negro y dorado, de dos varas y tres cuartas de alto, de doce tablas en 200 pesos" (I747), ${ }^{137}$ "Uno dicho [rodastrado], con I2 hojas, maqueado de negro, en 60 pesos" (finales del siglo XVIII) ${ }^{138}$ y "Un biobo, maqueado de negro, de I2 hojas, con sus tarjas de pintura, en 30 pesos" (finales del siglo XVIII). ${ }^{139}$ Aunque los

135. Se advierte el contraste entre el escritorillo de María Correa y "Dos escriptorios de maque de China negros, pintados de flores de colores y pájaros, de media vara de alto y media de ancho, en sesenta pesos ambos", AGn, Civil, "Inventario de bienes de Juan de la Rea, Caballero de la orden de Alcántara (1708)”, vol. 137, exp. I, f. 29.

I36. Dobado González, "La globalización hispana”, I4-I5 y 38.

137. Curiel, "Los biombos novohispanos", 29.

I38. AGN, Vinculos y Mayorazgos, Quaderno $2^{\circ}$ de inventarios, finales del siglo xviII, vol. I4I, ff. I3-I5V.

I39. AGN, Vinculos y Mayorazgos, Quaderno $2^{\circ}$ de inventarios, finales del siglo XVIII, vol. I4I, ff. I3-I5v. 
biombos chinos de maque negro de doce hojas podrían ser de Coromandel (fig. 2), la falta de detalles impide afirmarlo. Las diferencias significativas de precio entre las obras sugieren distintos tipos de trabajo. Quizá sea más factible que el biombo tasado en 200 pesos sea de Coromandel. Pese a las omisiones sobre la calidad y el estado de conservación, es improbable que los biombos negros de $\mathrm{I} 2$ hojas tasados a 30 y 60 pesos se hayan considerado de muy buena calidad o en excelentes condiciones.

En China se hicieron biombos negros de laca específicamente para el mercado occidental (fig. 7), ${ }^{140}$ que exhiben paisajes y escenas de montería, enmarcadas por diseños florales. La avidez por los biombos chinos permite suponer que en la Nueva España circularon algunos ejemplares. Además de las referencias mencionadas, aquí se localizaron otras a ocho biombos "chinos" (I704-1784). Se mencionan los precios de siete obras, que van de 50 pesos por "Un biombo. De maque de China, de seis tablas" (I708) ${ }^{141}$ a 240 pesos por "Otro dicho, también de maque de China, mayorcito" (I784). ${ }^{\mathrm{I}}{ }^{2}$ Aunque se omiten detalles sobre la apariencia o color de las obras, al parecer se trata de producciones de cierta calidad, que podrían haber sido chinas.

Alberto Baena Zapatero ha informado que "entre las propiedades del maestre de Campo de la ciudad de Manila, don Esteban de Eguiño, se incluyen 'doce tablas de maque negro para biobo de estrado' que pudieron ser montadas por algún artesano especializado o reutilizadas en la elaboración de otro tipo de muebles como en ocasiones sucedía en Europa." "I43 Se ignora el origen de las tablas, pero podría tratarse de una producción manileńa — de la que más adelante se comentarán otros indicios. En cualquier caso, en Manila - y, por tanto, en la Nueva Espańa - circularon paneles de laca china negra destinados a satisfacer el gusto virreinal por los biombos chinos. Por otro lado, en Japón en la época Edo se hicieron algunos biombos negros de laca (fig. 8). Aunque el flujo de obras japonesas a la Nueva España disminuyó a partir de 1630, en Manila siguieron circulando mercancías de dicho origen. ${ }^{144}$

I40. Forray-Cartier y Kopplin, Les Secrets de la laque française, 30.

I4I. Vargaslugo y Curiel, Juan Correa, III, 196.

I42. Curiel, "Los biombos novohispanos", 32.

I43. Baena Zapatero, "Un ejemplo de mundialización", 37-38.

I44. Teresa Canepa, "Namban Lacquer for the Portuguese and Spanish Missionaries", Bulletin of Portuguese-Japanese Studies, vols. I8-I9 (junio-diciembre, 2009): 260. 
7. Fragmento de un biombo de laca, China, siglo XVIII, $251 \times 46 \times 3 \mathrm{~cm}$. Museo de Artes Decorativas de Lyon.

Imagen tomada de Forray-Carlier y Kopplin, Les Secrets de la laque française (vid supra n. IOI), 30-3I.

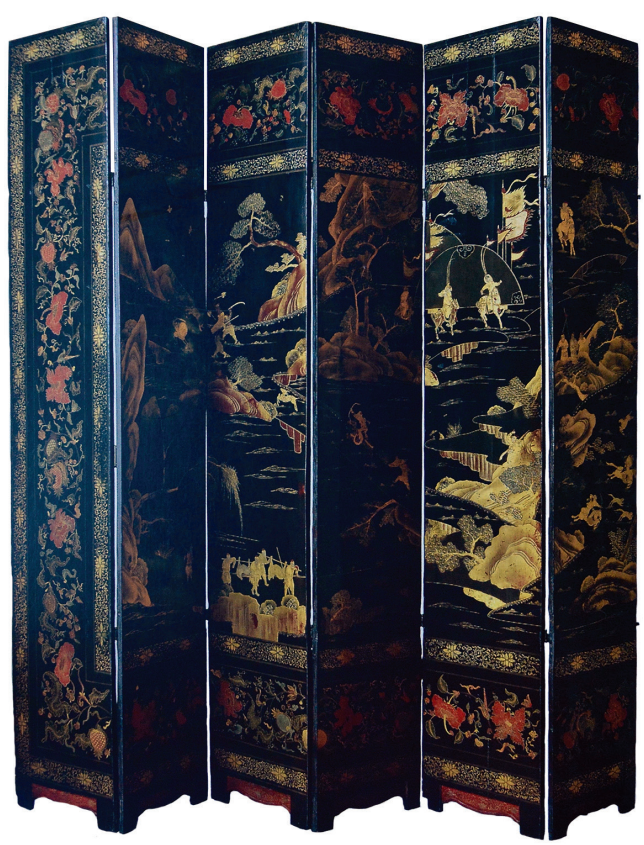

Asimismo, hubo biombos ingleses de japanning negro poblados por figuras achinadas. ${ }^{145}$ Recientemente se ha advertido que la producción española de lacas incluyó biombos, probablemente de buena calidad. ${ }^{146} \mathrm{Al}$ margen de los

I45. Véase The Dictionary of English Furniture, vol. 3 (ed. revisada por Ralph Edwards, Londres: Antique Collectors' Club, 1954), 57.

I46. El inventario de bienes de Isabel de Farnesio, de 1746, registra entre los charoles, "Otra Mampara nueba egecutada en el R.I Sitio de S.n Ildepho. fondo negro matizado de ramos dorados flores de distintos colores, y Pajaros todo de realce con Copete de lo mismo, y un Canastillo de fruta en el medio", en Ordóñez Goded, "De lacas y charoles", 39ı. Ordóńez Goded advierte que "En los documentos del siglo XVıII [...] se incrementa la presencia de [los biombos] en España, llegando a ser una de las manufacturas asiáticas más apreciadas [...] así como elementos de prestigio dentro del ajuar doméstico de las élites del momento. Los biombos, a menudo occidentalizados, que llegaban a América y a Europa a través de la nao de Acapulco tuvieron enorme éxito en ambos continentes. [En el] inventario de pinturas, alhajas y muebles del Palacio de San Ildefonso del año 1774 [se mencionan] Dos mamparas de charol, la una de charol de la china, y la otra hecha en España, á imitación de la antecedte tiene seis pies y medio de alto, estan en la casa de Alajas...”, 232. 
orígenes de los biombos mencionados en los documentos, hay referencias a otros objetos cuya descripción y precio sugiere un trabajo parecido. Por ejemplo, "Dos escriptorios de maque de China negros, pintados de flores de colores y pájaros, de media vara de alto y media de ancho, en sesenta pesos ambos"

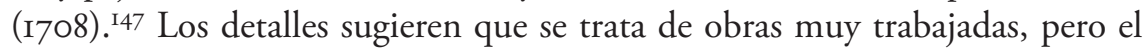
precio es mucho más bajo que el del escritorillo antes comentado y similar al de los biombos negros tasados a 30 o 60 pesos. Aunque las lacas en general se asociaron a cierto lujo, su éxito dio lugar a producciones diversificadas — tanto transpacíficas como trasatlánticas- que aún no conocemos bien y que, en ocasiones, podrían haberse especializado en obras relativamente asequibles.

Algo distinto es el caso de los biombos "chinos" de laca roja, de los que se localizaron tres referencias en documentos de 1747: "Un biombo de China, maqueado de encarnado y oro, con doce tablas y sus remates dorados en 300 pesos"; 148 "Un biombo nuevo, de la China, maqueado de encarnado y dorado, de dos varas y tres cuartas de alto, con doce tablas y sus remates dorados en 500 pesos" 49 y "Un rodaestrado de la misma fábrica, con veinticuatro tablas, de maque encarnado y dorado, y sus remates de lo mismo en 500 pesos". ${ }^{50}$

El precio de las tres obras es muy alto - los ejemplares de 500 pesos se sitúan sólo por debajo del escritorillo antes comentado y de un reloj de sala inglés, discutido más adelante. Aunque los tres biombos deben de haber sido de buena calidad, el de I2 tablas de 500 pesos es de especial interés; recuérdese que el precio más alto alcanzado por un biombo chino de I2 tablas de maque negro es de 200 pesos, en el mismo año (I747). ${ }^{\mathrm{ISI}}$

En sí mismas, las referencias no permiten determinar el origen de estos biombos. Al parecer, en otros ámbitos occidentales circularon pocos biombos chinos de laca roja. ${ }^{152}$ Sin embargo, en Inglaterra y parte de Europa las sillas de laca roja de japanning fueron tan gustadas que empezaron a ser imitadas por los talleres chinos de laca de exportación; es decir, hubo cierta adaptación al mer-

I47. AGN, Civil, "Inventario de bienes de Juan de la Rea, Caballero de la orden de Alcántara (I708)", vol. I37, exp. I, f. 29.

148. Curiel, "Los biombos novohispanos", 29.

I49. Curiel, "Los biombos novohispanos", 29.

I50. Curiel, "Los biombos novohispanos", 29.

I5I. "Otro biombo de China, negro y dorado, de dos varas y tres cuartas de alto, de doce tablas en 200 pesos". Curiel, "Los biombos novohispanos", 29.

I52. Entre los biombos chinos de exportación hubo, esporádicamente, ejemplares rojos, véase Forray-Carlier y Kopplin, Les Secrets de la laque française, 30. 


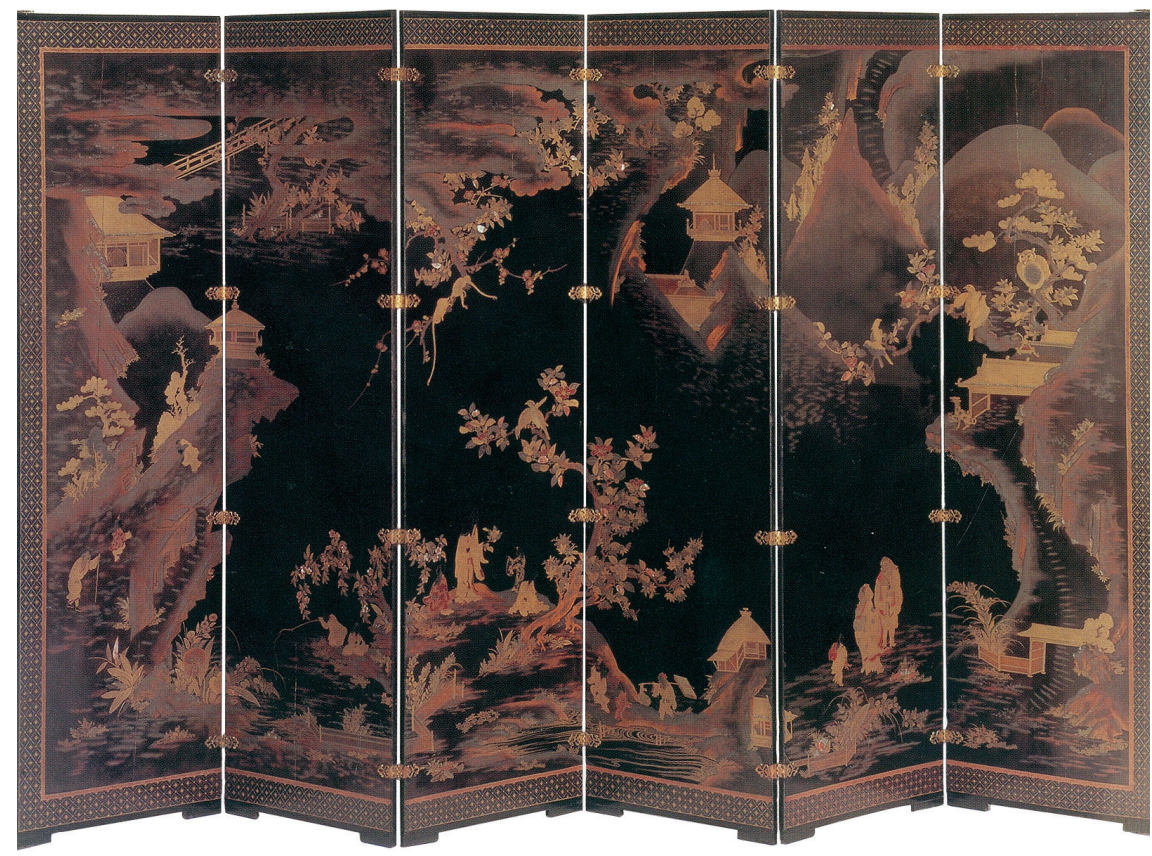

8. Biombo de laca de seis hojas, Japón, I660-1680, I71.6 $654.5 \mathrm{~cm}$ cada hoja. Victoria and Albert Museum, Londres. Imagen tomada de Impey y Jörg, Japanese Export Lacquer (vid supra n. 76), I9I.

cado occidental. ${ }^{153}$ Una parte de esa producción podría haberse comercializado en Manila. Baena Zapatero ha localizado una mención a un "beobo de maque colorado con flores doradas de dos caras de 24 hojas" embarcado en Manila rumbo a Acapulco en 1770. ${ }^{154}$ Asimismo, en el cargamento del Nuestra Señora del Carmen (1769), junto a materiales venidos de Cantón para producir canapés o taburetes de maque, aparece "un cajón con cincuenta y dos hojas de loza de maque colorado para dos beobos". "I5s Baena Zapatero sugiere la posibilidad de

153. David S. Howard, A Tale of Three Cities: Canton, Shanghai and Hong Kong; Three Centuries of Sino-British Trade in the Decorative Arts, catálogo de exhibición (Londres: Sotheby's, 1997), núm. 225.

I54. AGI, Filipinas, leg. 967, f. I2Iv, citado en Baena Zapatero, "Chinese and Japanese Influence on Colonial Mexican Furniture: The Achinado Folding Screens”, Bulletin of Portuguese-Japanese Studies, vol. 20 (junio, 20I0): Ioo.

I55. Baena Zapatero, "Un ejemplo de mundialización", 37-38, y Baena Zapatero, "Reflexiones en torno al comercio de objetos de lujo en el Pacífico siglos XVII y XVIII", en $A$ soo años del hallazgo 
que en Manila se manufacturaran biombos, entre otros muebles de maque, o de que hubiera talleres donde se remataran las piezas enviadas desde China. ${ }^{156}$

Conviene tomar en cuenta que existió un intenso tráfico comercial entre Macao, Cantón y Manila. Si bien en Cantón se hicieron y distribuyeron mercancías destinadas a distintos mercados europeos, parte de la producción artística de Macao — que se hallaba bajo el influjo portugués — puede haberse destinado a satisfacer los gustos hispanoamericanos (fig. 9) que, como se advierte, constituyeron un mercado tan importante como poco conocido en la historiografía internacional. ${ }^{157} \mathrm{La}$ existencia de numerosos biombos mexicanos achinados rojos de maque o al remedo de maque (fig. Io) afianza la idea de que los modelos en los que se inspiraron tuvieron particular éxito.

Por otro lado, algunos biombos de laca roja podrían haber sido de japanning inglés. ${ }^{158}$ Las lacas de japanning rojo circularon mucho en el mercado español; principalmente las de figuras doradas achinadas. ${ }^{159}$ La Compañía Británica de las Indias Orientales (EIC) solía llevar muebles ingleses sin terminar como lastre de los navíos rumbo a Asia, donde se desembarcaban para su decoración en talleres de laca, primero en Tonkin (Indochina) y más tarde en Amoy y Cantón. ${ }^{160}$ Las obras resultantes combinaban la carpintería inglesa, considerada superior, con la laca asiática. Como esto amenazaba el mercado

del Pacifico. La presencia novohispana en el Mar del Sur, Carmen Yuste López y Guadalupe Pinzón Ríos, coords. (México: Universidad Nacional Autónoma de México, 2016), 22I.

I56. Baena Zapatero, "Un ejemplo de mundialización", 37-38.

157. Aunque no se ha comprobado que obras como la de la figura 9 se hayan hecho en Macao, hay pocas dudas de su origen chino, y sus características permiten descartar que se hayan hecho en Cantón; de ahí que lo más factible sea que se trate de trabajos hechos bajo el influjo portugués en Macao.

I58. Curiel, "Una caja de maque de Michoacán”, 3II-3I2. Sin embargo, Ordóńez Goded señala que en los documentos españoles escasean las alusiones a los muebles de japanning, pues sólo encontró un biombo de japanning rojo, en una relación de bienes de 1728: "Otro [friso] de charol encarnado de Inglaterra". "De lacas y charoles", 279.

I59. Uno de los más famosos fue $A$ Treatise of Japanning and Varnishin, de John Stalker y George Parker (I688). Su intención no necesariamente fue copiar los objetos asiáticos pues, aunque los diseños derivaban de aquéllos, los habían "Ayudado un poco en sus proporciones, donde estaban cojos o defectuosos, y los habían hecho más agradables sin dejar de ser antiguos". Stalker y Parker, A Treatise on Japanning and Varnishing (Londres, I688; reimpreso, Londres, 1960, I97I), XVI (la traducción es mía).

I6o. Esta práctica había sido iniciada por la Compañía Holandesa de Indias Orientales (voc), que había llevado muebles holandeses a Japón para que los lacaran y ornamentaran. Kopplin, European Lacquer, 70. 




9. Biombo de laca de seis hojas, ¿Macao?, siglo XVIII o XIX, $240 \times 324 \mathrm{~cm}$. Anónimo, colección particular. Imagen cortesía de Alan Rubin, Pelham Galleries, París-Londres.

inglés, los lacadores ingleses se interesaron en expandir su mercado al centro y sur de Europa, incluyendo España. ${ }^{161}$

$\mathrm{Al}$ respecto, destaca Giles Grendey (1693-1780), prestigioso mueblero cuyas lacas tuvieron un mercado importante en otras naciones, incluyendo España. ${ }^{162}$ Grendey fue autor de un lote de unas 77 lacas achinadas rojas de figuras dora-

I6I. Kopplin, European Lacquer, 70. El fenómeno trasciende a Grendey. Por ejemplo, los bienes del primer marqués de Campoflorido (1726) incluyeron "un salón compuesto de treinta y seis piezas en charol encarnado [...] que alcanzó la cifra de I2.00o reales y otro casi idéntico pero en charol negro", obras inglesas de exportación. María Paz Aguiló Alonso, "Via Orientalis' 1500-1900. La repercusión del arte del Extremo Oriente en España en mobiliario y decoración", en XII Jornadas Internacionales de Historia del Arte. El arte foráneo en España. Presencia e influencia (Madrid: Consejo Superior de Investigaciones Científicas, 2005), 533.

162. Anónimo, "Dos nuevas piezas en el MNAD: Los cabinets de Giles Grendey", Estrado. Boletín del Museo Nacional de Artes Decorativas, Gabinete de Curiosidades II (20II): I29. 


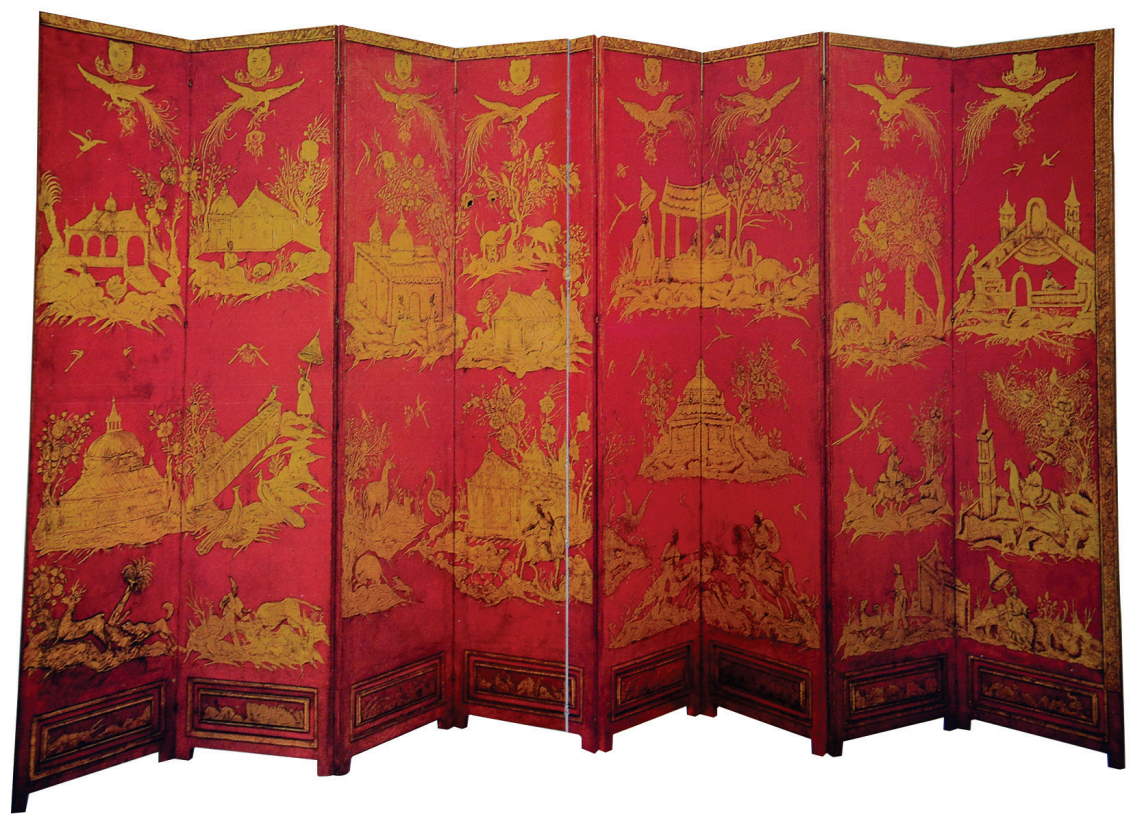

Io. Biombo achinado de ocho hojas, Nueva España, segunda mitad del siglo XviıI, s.m. Colección particular, México. Imagen tomada de El mueble mexicano (vid infra n. 215), fig. I64.

das (sillas, sillones, cabinets, mesas de juego, espejos, camas de día) conservadas en el palacio de Lazcano hacia 1730-1740. ${ }^{163}$ Según el Boletin del Museo Nacional de Artes Decorativas de España, de su taller:

salieron todo tipo de piezas de mobiliario, desde muebles de asiento, a espejos o muebles de guardar, en maderas nobles en su color, nogal y caoba, o bien maderas más corrientes lacadas o jappanning $[s i c]$, imitación de las lacas orientales, muy de moda por entonces, y decoradas a base de chinerías. La mayor parte de las piezas exportadas eran lacadas, como el conjunto de Lazcano, y según algunos investigadores como Symonds, en España y Portugal se prefería la laca roja. Dichos inves-

163. Según Cristina Ordóñez Goded, acaso se trate del mayor conjunto de mobiliario hecho en Inglaterra durante el siglo XviII, "Japanning en España. Un lote de muebles de laca escarlata realizado por Giles Grendey”, Estudi del Moble, núm. I4 (20II): I4. 
tigadores sostienen que la laca negra era más del gusto anglosajón, por lo que tuvo menos difusión en el mercado europeo. ${ }^{164}$

La domesticación novohispana del japanning dirigido al mercado hispanoamericano trasciende el trabajo de Grendey. Desde luego, en las obras europeas la cercanía con los modelos asiáticos varió notablemente y en la Nueva España se reconoció, en ocasiones, que algunas lacas rojas notables no eran chinas, sino achinadas. Destaca la referencia del inventario de bienes del conde de Xala (1784) a "Un Relox de Sala, con su Caxa Maqueada de Bermellon, achinada, con diario, en trescientos pesos". ${ }^{165} \mathrm{La}$ obra sin duda corresponde al japanning inglés, que incluyó una importante producción de relojes. ${ }^{166} \mathrm{Al}$ parecer, en los ámbitos hispanos el gusto por esas obras fue introducido por Isabel de Farnesio. ${ }^{167}$

Las lacas que los documentos llaman chinas incluyen algunas cuyas características difieren de la mayoría de las obras conocidas, de modo que son especialmente difíciles de acercar a alguna producción determinada. Al respecto destacan los biombos cuyos haces alternan un fondo rojo y otro negro: "Un biobo de tableros de doce hojas de China de maque encarnado y oro por un haz y por el otro negro en 250 pesos" (I737) I68 $^{16}$ "Un biobo de maque de China de dos haces, con doce tablas, carmesí y negro en 90 pesos" (I737). ${ }^{169}$

La combinación de dos colores en una misma obra es relativamente frecuente en las lacas europeas. En Inglaterra, en la época del rey Jorge II (I727I760), se hicieron biombos de japanning de dos haces, poblados por motivos achinados dispuestos sobre sendos fondos rojo y verde oscuro (figs. IIa y irb). Acaso las obras referidas en los documentos novohispanos correspondan a una elaboración similar. Por otro lado, también podría tratarse de una producción

I64. Anónimo, "Dos nuevas piezas", I29.

165. Romero de Terreros, Una casa del siglo XVIII, 60.

166. Kate Helwig, "Materials Analysis of a Japanned Long Case Clock", Journal of the Canadian Association for Conservation (J. CAC), núm. 26 (200I): 27-33.

I67. María Soledad García Fernández, "Muebles y paneles decorativos de laca en el siglo XviII", Oriente en Palacio, 344. También Felipe V gustó mucho de los relojes ingleses de laca. Ordóñez Goded, "De lacas y charoles", 268, n. I604.

I68. AGN, Vinculos y Mayorazgos, "Autos y almonedas de los bienes de don Pedro de Barrio del Orden de Santiago (I737)", vol. II, exp. 4, f. 4.

I69. AGN, Vínculos y Mayorazgos, "Embargo de los bienes de la testamentaría de don Pedro de Barrio del Orden de Santiago (I737)", vol. II, exp. 3, f. 4Ov. 
china - ya sea cantonesa o de Macao- destinada al mercado occidental, ${ }^{170}$ cuyo envío a la Nueva España podría haberse producido a través de Manila:

En el registro y descarga efectuados en 1769 a la chalupa Nuestra Señora del Carmen, que venía desde Cantón a Manila a cargo del capitán don Antonio Pacheco, encontramos "dos cajones largos sin número ni marca que contienen dentro dos beobos de maque blanco cada uno con doce hojas", valorados en 25 pesos cada uno. ${ }^{171}$

Después de que Gérard Dagly desarrolló el maque blanco a finales del siglo XVII, se hicieron ejemplares con distintas técnicas europeas, ${ }^{172}$ a menudo achinados (fig. I2), que circularon en la Nueva España; en I784, el conde de Xala poseía "Un Relox de Elicot, con Musica y Caxa de Maque blanco", tasado en mil pesos. ${ }^{173} \mathrm{El}$ pronunciado gusto europeo por las lacas conlleva cierto interés en "mejorar" las obras chinas y el precio de este reloj sugiere el reconocimiento a una calidad óptima. Quizá esto impulsó la producción china, cuyas técnicas hasta entonces no habían permitido elaborar lacas blancas.

El envío de 1769 sugiere que en Cantón se desarrollaron procedimientos — quizá informados en los europeos— para satisfacer el gusto occidental por la laca blanca y acceder así a un mercado más amplio. De cualquier modo, en Macao hubo producciones artísticas particulares de las que se sabe poco y que, aunque se destinaron principalmente al mercado portugués, pudieron haber

170. Al respecto la única referencia aquí registrada es la de Ordóńez Goded a "un biombo de doce hojas de laca bicromática roja y negra del siglo xvinI, quizá chino que se conserva en el Museo del Disseny de Barcelona. Presenta en el anverso episodios de la historia de Don Quijote y en el reverso una leyenda china". "De lacas y charoles", 254. Por otro lado, al parecer hubo una producción indoportuguesa de biombos de laca que combinaron el negro y rojo en un mismo haz. Al respecto véase el ejemplar subastado en Christie's Londres, "Kinross House, Scotland And Property Removed From The London Residence of Mrs. Winston Spencer Churchill”, consultado el 30 de marzo de 20II, www.christies.com/lotfinder/Lot/an-indo-portuguese-black-gilt-and-redjapanned-four-fold-5418493-details.aspx.

I7I. Baena Zapatero, "El movimiento de biombos", 37.

172. También hubo obras españolas, sobre todo a mediados del siglo xviII. Ordóńez Goded, "De lacas y charoles", 684-686, 691 y 798.

173. Romero de Terreros, Una casa del siglo XVIII, 6o. Este reloj debe de haber sido excepcional, pues el documento registra una obra parecida cuyo precio, aunque alto, representa apenas una fracción del de aquél: "Un Relox de Sala, con su Caxa Maqueada de Bermellon, achinada, con diario; en trescientos pesos". Romero de Terreros, Una casa del siglo XVIII, 60. 
DOI:http://dx.doi.org/10.22201/iie.18703062e.2017.111.2611.

I72

SONIA I. OCAÑA RUIZ
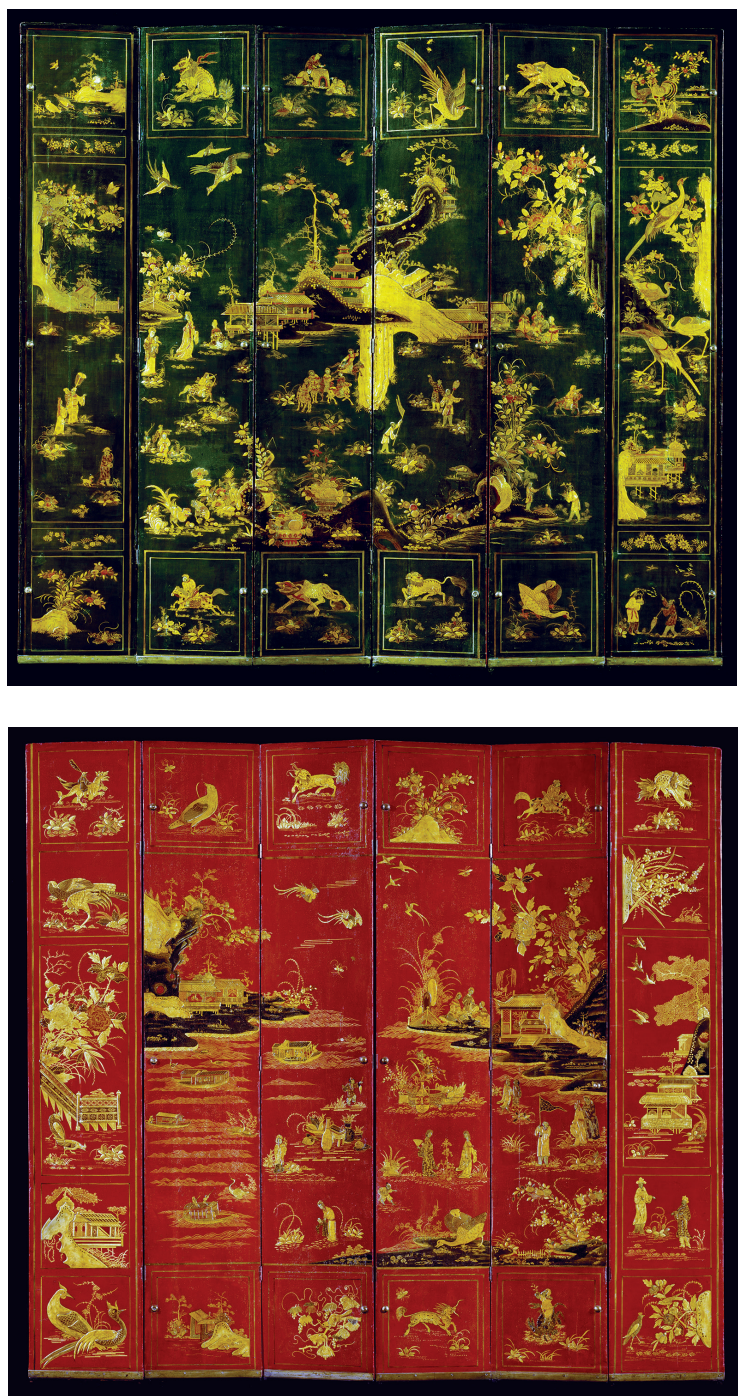

IIa y irb. Biombo de japanning de seis hojas y dos haces, Inglaterra, ca. I730, $276 \times 50 \mathrm{~cm}$ cada hoja. Colección particular. Imágenes cortesía de Alan Rubin, Pelham Galleries, París-Londres. 


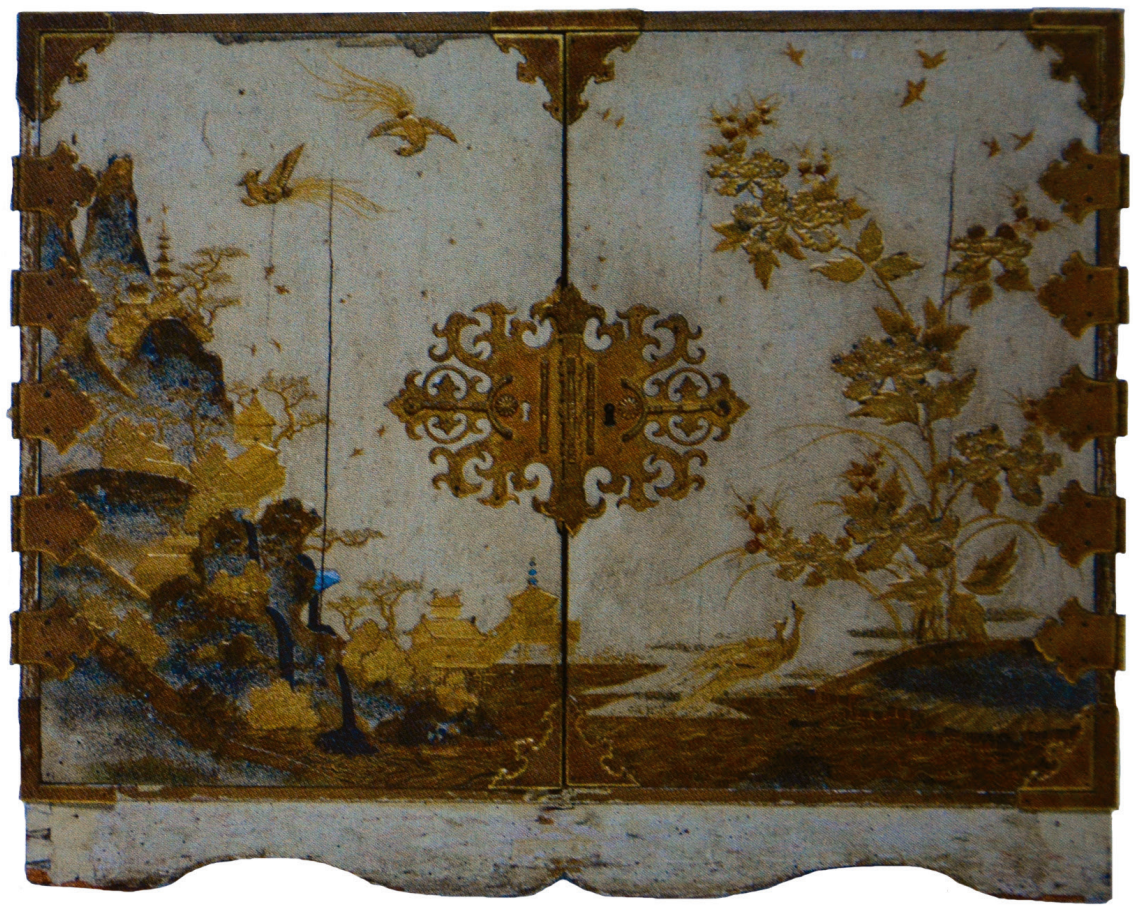

I2. Gérard Dagly, papelera de laca blanca, Berlín, finales del siglo xviı. Herzog Anton UlrichMuseum, $70 \times 90.5 \times 41.5 \mathrm{~cm}$. Imagen tomada de Gérard Dagly und die Berliner Hofwerkstatt (Múnich: Hirmer, 2015), 46.

incluido el virreinal. ${ }^{174}$ Asimismo, Impey y Jörg señalan que en Japón hubo a finales del siglo XvıI una pequeña producción de "laca" blanca, destinada tanto al consumo doméstico como a la exportación. Al parecer la técnica no se ha analizado, pero en Japón se cree que consiste en tiza en polvo, mezclada con laca incolora. Las obras se conservan en muy malas condiciones. ${ }^{175}$

174. Agradezco al señor Alan Rubin, de Pelham Galleries, sus sugerencias respecto a esta posibilidad. En cuanto a otros tipos de biombos probablemente hechos en Macao y escasamente conocidos en Europa, véase Francisca Figueira, Philip Meredith y Ana Clara Rocha, "A Sino-Japanese-Portuguese byobu: its Conservation and Restoration", consultado el to de diciembre de 20I5, en www.patrimoniocultural.gov.pt/static/data/conservacao_e_restauro_ljf/ publicacoes2/20II_a_sino_japanese_portuguese_byobu.pdf.

175. Impey y Jörg, Japanese Export Lacquer, 136 y 256. Por su parte, la página web del Museum für Lackkunst de Münster señala "Como la laca de Asia oriental era tan agresiva y tóxica, en 
El estado actual de la investigación impide ofrecer respuestas definitivas sobre los orígenes de muchas de las lacas que los documentos llaman chinas - ya sea negras, rojas, rojas y negras, o blancas. El estudio de este tema requiere tener en cuenta que en el siglo XviII el mercado de las lacas fue muy amplio y estuvo segmentado, y que las producciones asiáticas, europeas y novohispanas se adaptaron constantemente a los gustos de los consumidores. Así pues, las respuestas más importantes derivan de las interrogantes sobre los gustos del público, que aún no se conocen lo suficiente.

\section{Las lacas novohispanas de técnica europea}

La importancia de las lacas europeas achinadas en los procesos novohispanos de "domesticación de Asia" del siglo xviıI va más allá de la circulación de ejemplares. En esta investigación se localizó el embargo de los bienes de la testamentaría de Pedro de Barrio, caballero del Orden de Santiago (1737), que incluye, entre otras lacas, "Un escaparate maqueado de oro y encarnado, con sus vidrios finos, como de a tres varas, vacío" ${ }^{176}$ Durante los Autos y Almonedas de los bienes se pregunta a los testigos "si también les consta, que el escaparate de maque encarnado, con sus vidrios grandes, que estaba en la sala del estrado [...] lo hizo de orden de dicho difunto el carrocero Antonio Cuerbo, y se lo pagó". ${ }^{177}$ Posteriormente se añade que la obra posee "vidrios de cristal de varios tamaños y se apreció en

tiempos pasados sólo podían usarse para colorearla unos pocos pigmentos naturales. En general no era posible hacer laca blanca. Así pues, para poder producir el color blanco para los diseños decorativos y los fondos, se usaban cáscaras de codorniz en pedazos pequeños o finamente molidas que se colocaban en la laca aún húmeda. Esta técnica de laca era y es tradicionalmente usada en el sureste asiático, en particular". ("Since East Asian lacquer was so aggressive and toxic, there were only a few natural pigments that could be used for coloring it in former times. It was generally not possible to make white lacquer. So as to still be able to produce the color white for designing décor and grounding whole areas, shells from quails' eggs were broken into small pieces or ground to a powder and then placed on the still-wet lacquer. This lacquer technique was and is traditionally applied in Southeast Asia in particular"), en "E as in Eggshell decoration", consultado el 20 de octubre de 20I6, www.museum-fuer-lackkunst.de/en/abc_of_lacquer.

176. AGN, Vinculos y Mayorazgos, "Embargo de los bienes de la testamentaría de don Pedro de Barrio del Orden de Santiago. México (I737)", vol. II, exp. 3, f. 7.

177. AGN, Vinculos y Mayorazgos, "Autos y almonedas de los bienes de don Pedro de Barrio del Orden de Santiago (I737)”, vol. II, exp. 4, f. I7v (las cursivas son mías). 
I70 pesos". ${ }^{178} \mathrm{Al}$ reclamar la propiedad de los bienes, la viuda asegura: "De la estufa y escaparate depone el mismo carrocero quien lo hizo de orden y mandato de dicho Don Pedro". ${ }^{179}$

Hasta ahora se ignoraba que los carroceros capitalinos hubieran hecho escaparates de laca. Sin embargo, la información no es del todo sorprendente, pues se conocían las referencias a "un forlón de maque, de pintura fina" (I7I8) y a "Una silla de manos, nueva, pintada de maque azul, y por dentro de raso de China listado" (finales del siglo XVIII), procedentes de sendos inventarios de bienes de San José de Parral, Chihuahua, ${ }^{180}$ y Puebla. ${ }^{181}$ No es seguro que se trate de ejemplares novohispanos achinados. Ahora bien, como los coches de laca emplearon exclusivamente técnicas europeas, ${ }^{182}$ ambas obras corresponden a la misma producción que el escaparate de Barrio, ${ }^{183}$ cuya tipología y paleta coinciden con los modelos de japanning inglés que circularon en Hispanoamérica.

El documento de Barrio es de la época en la que Felipe V e Isabel de Farnesio estaban redecorando su dormitorio con lacas. A diferencia de la Península Ibérica, en la Nueva España no hubo —al parecer- charolistas, lo que no impidió que en la Nueva España se hicieran lacas de técnica europea. El gremio capitalino de carroceros, desprendido del de carpinteros, se había organizado en I706. De momento se ignora qué técnicas emplearon en las lacas, pues sus Ordenanzas no mencionan este tipo de trabajo. ${ }^{184}$

178. agn, Vinculos y Mayorazgos, "Autos y almonedas de los bienes de don Pedro de Barrio del Orden de Santiago (I737)", vol. II, exp. 4, f. 29.

I79. agn, Vinculos y Mayorazgos, "Autos y almonedas de los bienes de don Pedro de Barrio del Orden de Santiago (I737)”, vol. II, exp. 4, f. 37v (las cursivas son mías).

I80. Curiel, "Cuatro inventarios", 253.

I8I. Curiel, "Introducción", 28.

I82. Agradezco los comentarios de Monika Kopplin, quien me indica que, por su delicadeza, las lacas asiáticas no habrían podido usarse para hacer coches, de modo que todos los coches de laca son europeos.

I83. Según Ordóńez Goded, "Del contenido de las fuentes consultadas, es posible establecer que, aunque en el pasado existían en España artífices dedicados exclusivamente a las tareas de lacado, este arte no siempre constituía una profesión en sí misma, sino que los especialistas [...] se ganaban el sustento con otros oficios artesanales como el dorado, la pintura ornamental, el barnizado [...] De ahí la multiplicidad de nombres que recibían en función de los diferentes ámbitos de producción, zonas geográficas, periodo histórico, etc.”, "De lacas y charoles”, 668. Véase también 79-80, n. 326.

I84. Ordóñez Goded considera que el lacado en los carruajes españoles pudo haber iniciado a mediados del siglo XviII, coincidiendo con el auge por la laca en toda Europa, aunque también cabe la posibilidad de que los métodos empleados hayan tenido más similitudes con la pintura sobre 
Álvaro Recio Mir ha advertido que los carroceros se concentraron en la ornamentación, esencial para la valoración económica de sus obras. ${ }^{185}$ Quizá en la Nueva España las lacas de técnica europea se asociaron a aquéllos porque su trabajo se concentró en los detalles que exhibían lujo, no en la carpintería. La incursión de los carroceros en los objetos de laca demuestra que su trabajo fue flexible y que ampliaron su mercado al cubrir necesidades que rebasaban la realización y el decorado de los coches.

Por otro lado, en la propia metrópoli se relacionó el trabajo de los carroceros y los charolistas. En 1772, Carlos III reconoció a los carroceros extranjeros la facultad de ejercer su oficio. En la Real Cédula respectiva se citó el caso de Simón Garrou, "de nación francés, vecino de Madrid, maestro charolista y de hacer coches, aprobado por la corte de París" ${ }^{186}$ Es decir, al margen de lo estipulado en las Ordenanzas, a ambos lados del Atlántico los carroceros incursionaron en el trabajo de maque. ${ }^{187}$ Documentalmente se sabe que en España hubo numerosos coches de laca, de precios altos. ${ }^{\mathrm{I} 8}$ Cabe suponer que las técnicas de Cuerbo fueron cercanas a las europeas. ${ }^{189}$

Aunque el documento de Barrio no menciona si el escaparate era achinado, la referencia al maque encarnado y de oro así lo sugiere. Durante el embargo de los bienes, uno de los testigos señala que "la loza de China que encerraba

tabla, con el añadido de sucesivas capas de barniz que con auténticas operaciones de lacado. "De lacas y charoles", 434 .

185. Álvaro Recio Mir, "Evolución de la carrocería novohispana en el siglo XviII: segundas ordenanzas del gremio de la Ciudad de México", Historias, núm. 8I (20I2): 26-27.

I86. Recio Mir, "Evolución”, 23 (las cursivas son mías). Asimismo, el madrileño Diario Noticioso anunció en 1758 "acaba de llegar a esta Corte un hombre hábil en componer Charoles y Barnices, con el mismo gusto, y primor, que lo hacen en Francia, y en Inglaterra. Este sujeto, dice saber hacer tambien Coches, Berlinas, y Sillas de manos al gusto extranjero", Diario Noticioso, 9 de febrero de 1758, citado en Ordónez Goded, "De lacas y charoles", 385.

I87. En I863, Antonio García Pérez señaló, en relación con las lacas de Uruapan, que "El barniz con que cubren la pintura, dorado ó incrustado de esas piezas, es como el mejor que se dá á los carruajes de lujo". "Descripción", 475.

I88. Por ejemplo, el Diario de Madrid del 27 de diciembre de i8ro menciona entre los coches depositados en las cocheras del Nuncio: "Un forlon de gala, caxa charol, dorado, juego verde y dorado, forrado en terciopelo verde y blanco [...]"; "una berlina de gala, guarnecida de pedrería, con tableros de cobre, charol imitado a venturina verde, carro id. fileteado dorado [...]”; "un forlón correspondiente a la berlina anterior, charol dorado, y en todo igual a ella en 42 mil reales" y en el alfar calle de san Carlos: "una carroza con tableros de cobre, charol dorado imitado aventurina", núm. 56I, 799 y 800.

I89. Las técnicas se describen en Forray-Carlier y Kopplin, Les Secrets de la laque française, I2O-I2I y I75. 
dicho escaparate, la hubo el difunto de regalo, que en varias veces le enviaron sus amigos de Philipinas". ${ }^{190}$ Lejos de ser aleatoria, la exhibición conjunta de la laca achinada y la porcelana china sugiere que Barrio relacionó los objetos con ciertas concepciones sobre sus ámbitos de origen. ${ }^{19 I}$ Es decir, en la Nueva España, como en Europa, algunos individuos afianzaron su prestigio personal a partir de la familiarización con Asia, manifestada en la exhibición de gabinetes compuestos, indistintamente, de obras chinas y achinadas.

Es decir, las lacas de los carroceros se consideraron parte de la misma problemática que las asiáticas y las novohispanas de técnica prehispánica. El escaparate debió haber sido notable, pues se había hecho sobre pedido, se reservó al estrado $\mathrm{y}$ tuvo vidrios de cristal. Acaso el precio de 170 pesos se haya debido, en parte, a dichos vidrios. ${ }^{192}$ De cualquier modo, no hay duda sobre la calidad de la obra, elaborada por encargo a un precio más alto que otros escaparates de la época. ${ }^{193}$

El prestigio de las lacas de los carroceros novohispanos debe de haber derivado de su calidad. Aunque es difícil acercar la técnica de este escaparate a las obras conservadas, acaso se trate del mismo trabajo que el de un pequeńo retablo en forma de baldaquino (fig. 13) que contiene una Virgen de Guadalupe atribuida a José de Páez y datada a mediados del siglo XviII. ${ }^{194}$ La pieza se halla en la iglesia de Santa Catalina en Tacoronte, Tenerife; su fondo rojo está poblado por figuras doradas. Jesús Casas Otero ha comentado:

190. AgN, Vínculos y Mayorazgos, "Autos y almonedas de los bienes de don Pedro de Barrio del Orden de Santiago (I737)", vol. II, exp. 4, f. I7v. Respecto a la mención a los amigos de Filipinas, tiene interés la observación de Baena de que "el gusto por los productos orientales [...] fue si cabe más acentuado entre aquellos que tenían o habían tenido algún tipo de relación con el comercio del Pacífico, sirviendo en un principio como introductores y difusores". Baena Zapatero, "El movimiento de biombos", 75 .

I9I. Keating y Markey, "'Indian' Objects”, ıо.

192. En el inventario de bienes de la marquesa de San Jorge se registra un escaparate y mesa sobrepuesto de ébano y marfil, con vidrieras por delante y a los lados. El escaparate y la mesa se tasaron en 80 pesos, mientras que los vidrios se valuaron en 200 pesos. Curiel, "El efímero caudal", 8i y 83.

193. Por ejemplo, "Yt. un escaparate encarnado con llaves, y en él tres platones grandes, diez y ocho medianos, seis pozuelos, ocho tazas calderas, cinco tazas po [...] ras tres platones chicos, diez y ocho figuras quince tacitas chiquitas todo de loza fina de China: una taza grande con su tapa de cristal: diez y nueve vidrios de Venecia, cuatro vidrios más medianos y otro guarnecido de plata, un coquito guarnecido de lo mismo todo en ochenta y cinco pesos", Archivo General de Notarías de Puebla, Notaría I, caja I4, I724-1730, Gregorio de Mendizabal, ff. 518v-519.

194. Jesús Casas Otero, Estudio histórico-artístico de Tacoronte (Santa Cruz de Tenerife: Excmo. Cabildo Insular de Tenerife, 1987), 78. Agradezco a Antonio Marrero su amable ayuda para la documentación y el registro fotográfico de esta obra. 
13. Baldaquino de laca que contiene una imagen de la Virgen de Guadalupe con las cuatro apariciones y una escena de la huida a Egipto. Pintura de José de Páez (atribución), Nueva España, ca. $1750,84 \times 62 \mathrm{~cm}$. Iglesia de Santa Catalina de Alejandría, Tacoronte, Tenerife. Foto: cortesía de Antonio Marrero.

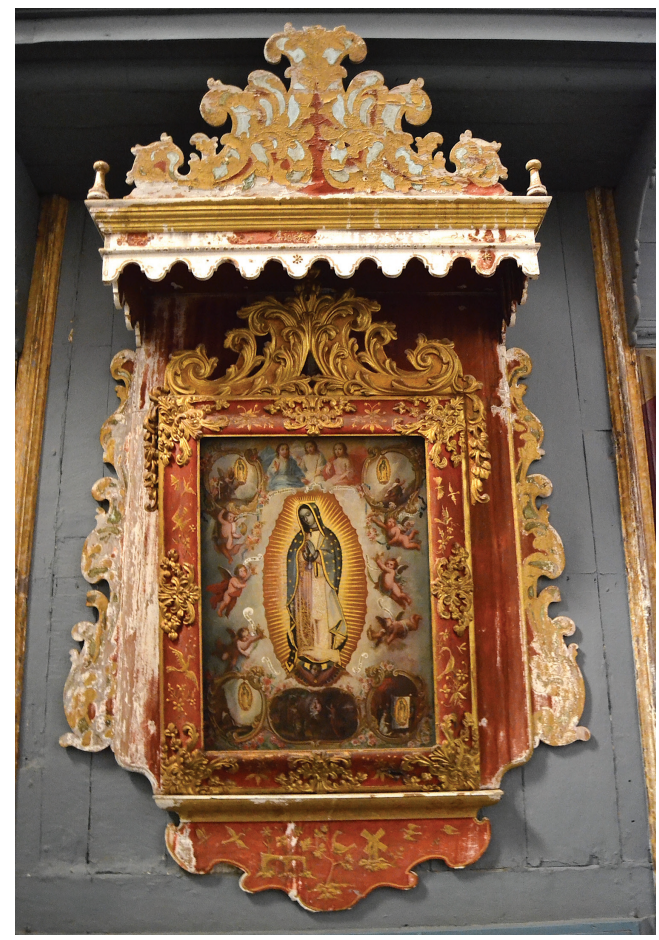

Junto a los tallos movidos del barroco mejicano [sic], destaca la menuda decoración de pájaros y flores, de notable influencia chinesca [...] De la parte baja, pende una placa recortada y rellena con estos elementos chinescos formando un paisaje de pájaros, árboles y flores, a los que se añade un puente y un molino de cuatro aspas. ${ }^{195}$

Esta obra se distingue por su cuidadosa factura, cercana a los modelos ingleses; por ejemplo, un marco de japanning negro de colección particular, datado hacia 1690-I710, que incluye secciones de un biombo de laca china. ${ }^{196}$ Dichos marcos no fueron muy comunes en Inglaterra ${ }^{197}$ y quizá tampoco en la Nueva España.

195. Casas Otero, Estudio histórico-artístico, 78.

196. www.coulborn.com/furniture-categories/mirrors/black-japanned-gilt-decorated-andcarved-giltwood-cushion-mirror/, consultado el is de octubre de 2015.

197. El Dictionary of English Furniture ilustra una obra hecha para el primer duque de Montagu y la otra para Ham House. Thomas Coulborn \& Sons Ltd Fine Antique Furniture and Works of Art, consultado el 23 de marzo de 20I6, en www.coulborn.com/furniture-categories/mirrors/blackjapanned-gilt-decorated-and-carved-giltwood-cushion-mirror/. Es lógico suponer que entre las piezas 
El hecho de que el novohispano también tenga uno, afianza la idea del importante papel que las lacas europeas desempeñaron en la domesticación de Asia. ${ }^{198}$

Al margen de la técnica, el escaparate de Barrio confirma el alcance de las lacas inglesas en la Nueva España, pues ese tipo de muebles en laca rojo bermellón y decorados con chinoiserie dorada son un prototipo inglés. Esbeltos, con puertas dobles — generalmente de cristal — y a menudo rematados por arcos pareados, combinaban un escritorio en la parte superior y una cómoda con varios cajones en la inferior. Su exportación a España, Portugal, Italia y Alemania dio lugar a variantes regionales. ${ }^{199}$ En la Nueva Espańa, su éxito podría relacionarse con la circulación de los modelos de Giles Grendey, a quien se atribuyen sendos escaparates de laca roja, uno de los cuales al parecer viene del lote del duque del Infantado (fig. I4). ${ }^{200}$

Ambas obras son de japanning rojo, con figuras doradas y una decoración de chinoiserie; las puertas muestran en el interior a un hombre y una mujer. En el caso de la obra que se cree perteneció al duque del Infantado, la mujer se encuentra a la izquierda y el hombre a la derecha, igual que ocurre en un escritorio novohispano de colección particular que combina un trabajo de taracea en el exterior y un interior de color azarcón (fig. I5). ${ }^{201}$ Su técnica no se ha analizado; sin embargo, dado su parecido con el trabajo de Grendey en cuanto a tipo de mueble, figuras y paleta, es posible que se haya hecho con técnicas de laca. ${ }^{202}$

de japanning rojo que circularon en Hispanoamérica hubo marcos. Ordóńez Goded registra una pareja de marcos de espejo de laca roja con chinerías doradas y plateadas en la iglesia de Santa María de Pozaldez, Valladolid. De acuerdo con la autora, se trata de obras inglesas de la primera mitad del siglo XVIII. Se cree que las obras llegaron a esa colección en el siglo XVIII, "De lacas y charoles", 527.

198. Téngase en cuenta que una parte significativa de las producciones inglesas se destinó al mercado internacional y se adaptó a sus gustos. Al respecto, el galerista Alan Rubin me ha señalado que dicho copete era habitual en los marcos napolitanos, de modo que su presencia en la Nueva España también pudo producirse por esta vía. Agradezco a Alan Rubin sus comentarios sobre este tema.

199. Kopplin, European Lacquer, 68.

200. La pieza pertenece al Art Institute of Chicago, cuya página web atribuye la autoría a Grendey. Consultado el 22 de octubre de 20i6, en www.artic.edu/aic/collections/artwork/1977I4. La segunda obra pertenece al Metropolitan Art Museum de Nueva York.

20I. No es seguro que éste sea el color original, pues la obra corresponde a la misma producción que sendos escritorios cuya forma y fondo rojo recuerdan el japanning inglés. Curiel, "Mobiliario. En torno a nobles maderas, dorados hierros, lúcidas geometrías y finas intarsias", en La colección de muebles del Museo José Luis Bello y González de Puebla (Puebla: Secretaría de Cultura, 2010), 86-89. 202. Curiel, "Mobiliario", 86-89. 
I4. Giles Grendey

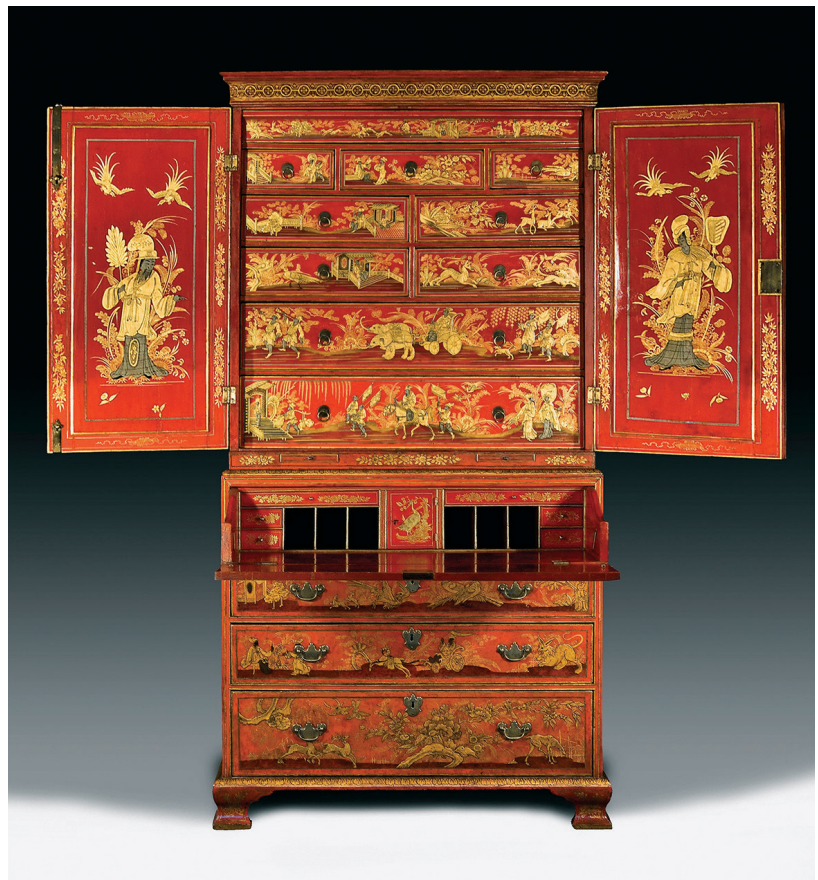

El parecido entre las obras de Grendey y el escritorio novohispano es limitado, pues este último tiene un perfil distinto y los cajones muestran un diseño de flores ajenas a los modelos ingleses. Aún así, este escritorio sugiere que los diseńos de Grendey llegaron a la Nueva Espańa por medio de imitaciones y fueron lo bastante exitosos como para que, a través de varias técnicas, los lacadores los hayan tomado como modelo para satisfacer las solicitudes de los comitentes. Así pues, incluso si técnicamente la obra de Barrio corresponde a una producción distinta a la del escritorio comentado, ambos corresponden al deseo de los comitentes de mostrar su familiarización con las lacas chinas a partir de los modelos achinados de origen inglés.

\section{La pintura y el maque fingido. Los biombos de maque achinado}

Las lacas asiáticas fueron la fuente de inspiración de algunas pinturas y muebles cuyo uso de las técnicas de laca es incierto, pero que sin duda reprodujeron sus 
efectos y soluciones (figs. Io y I6). En esta investigación se localizaron seis menciones documentales a obras de "maque fingido" o contrahecho, de las cuales tres son rodastrados. Particular interés tiene el de precio más alto: "Un rodaestrado achinado y maqueado fingido de veinte y cuatro tablas de a vara", tasado en 80 pesos (1732). ${ }^{203}$ Se ignora si el "maque fingido" remite a alguna técnica particular, ${ }^{204} \mathrm{O}$ si corresponde a la misma producción que los biombos que, según los documentos, combinaron el trabajo de maque y el de pintura. Por ejemplo, "Otro rodastrado de pintura y cotense maqueado con veinte tablas en 25 pesos" $(\mathrm{I} 727)^{205}$ y "Otro [biombo] sobre cotense, de dos haces, por un lado maqueado, y por el otro pintura, con diez tablas, se avaluó en cincuenta pesos" (I737). ${ }^{206}$

Estas últimas bien podrían haber combinado la laca y la pintura, como señalan sus descripciones. ${ }^{207}$ Ahora bien, acaso todo el trabajo haya sido pictórico y la mención al maque no obedezca a cuestiones técnicas, sino al parecido formal con las lacas asiáticas. ${ }^{208} \mathrm{Al}$ respecto, destaca una referencia de Manuel Romero de Terreros a:

un biombo pintado al óleo sobre tela [que] imitaba por un lado una mampara de laca de Coromandel, con tal maestría ejecutada, que solamente de cerca y al tacto se

203. AGN, Notaría I33, Juan José Cruz y Aguilar, I73I-I736, "Carta de dote de Juan Xavier Joachin Altamirano Legaspi, Albornos, Velasco, Ybarra, Ortiz, Oraci, Urrutia, de Vergara, Conde de Santiago Calimaia, Marqués de las Salinas y del Río, y Adelantado de las Islas Filipinas (I732)", vol. 837, f. I53v. 204. En su estudio sobre las lacas novohispanas, Castelló Yturbide expresa grandes dudas sobre este tipo de trabajo: "Quizá cuando los muebles no se maqueaban en Uruapan, se pintaban en Pátzcuaro, con esta técnica, empleando bermellón importado de China. Hay piezas de maque fingido tan profusamente decoradas con oro que obviamente, tuvieron que haberse hecho en Michoacán. Otra posibilidad es que el maque fingido haya sido especialidad de la Ciudad de México, pues a Puebla acudían artesanos de Olinalá expresamente a completar los trabajos de carpintería, sobre todo escribanías de marquetería que decoraban con sus maques de fondo azarcón, con técnica de rayado o dorado, en las que nunca aparecen figuras chinescas." El arte del maque, II.

205. AGN, Notaría 70, "Carta de dote Juan Baptista Claros (I727)", vol. 485, f. i7Iv.

206. AGN, Vinculos y Mayorazgos, "Embargo de los bienes de la testamentaría de don Pedro de Barrio Caballero del Orden de Santiago (I737)”, vol. II, exp. 3, f. 4 Ov.

207. Dicha combinación tuvo lugar en Europa. Arthur De Sandão, O móvel pintado em Portugal (Barcelona: Livraria Civilizaçao, 1999), 57-58, y Teresa Freitas Morna, "O interesse pelos acharoados na Europa. O impacto da técnica da laca”, en $O$ mundo da laca (Lisboa: Fundación Calouste Gulbenkian, 200I), 205-206.

208. Respecto a los biombos, Ballesteros Flores comenta que "además de la técnica que sigue de cerca la del maque asiático, hubo otras como el maque fingido, en el cual se emplearon materiales occidentales como la pintura al óleo o los charoles y maques occidentales." Ballesteros Flores, "El menaje asiático", 93-94. 
I5. Escritorio de taracea, pintado al remedo de maque en el interior. Nueva Espańa, siglo XVIII, $172 \times 76 \times 43$ $\mathrm{cm}$. Colección particular, México. Imagen tomada de El mueble mexicano (vid infra n. 215), fig. 17.

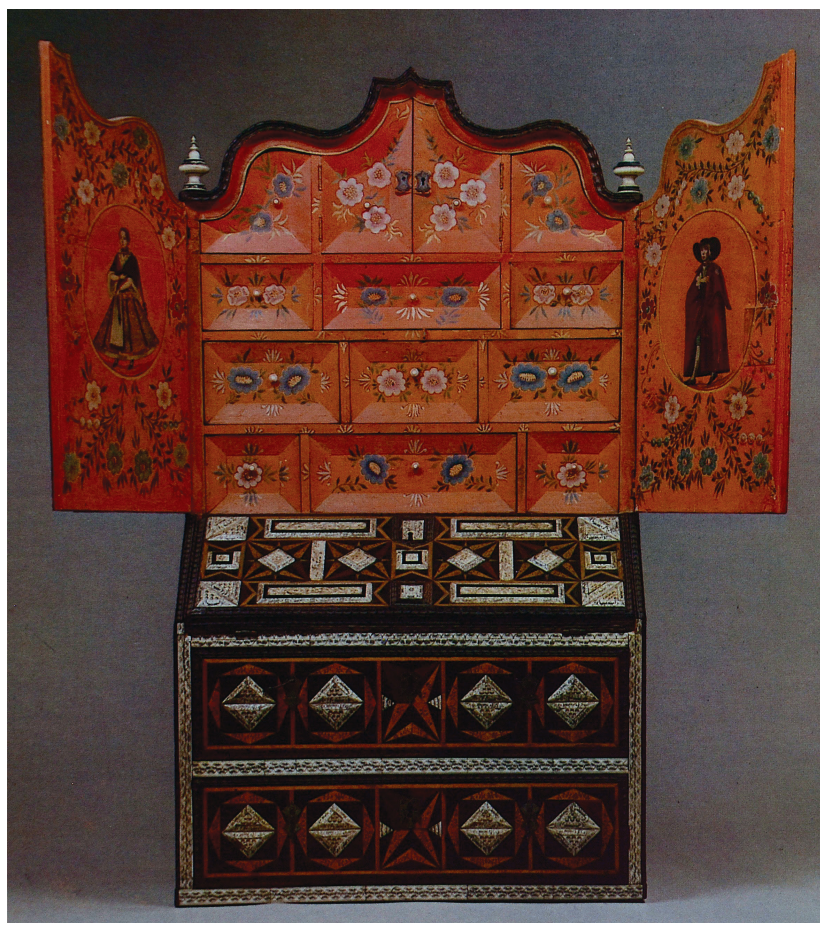

comprobaba que no estaba hecha de madera laqueada sino de pintura sobre lienzo. En el centro de una multitud de característicos motivos decorativos chinos se destacaba un gran medallón, poblado [...] de figuras europeas [...] pero interpretadas con criterio oriental [...] que el biombo fué confeccionado en la Nueva España lo comprueba plenamente su anverso, en el cual se representó una escena netamente mexicana. Es por lo tanto evidente que el anónimo pintor tuvo a la vista un legítimo biombo chino que copió por un lado, mientras que el otro lo ejecutó a mano libre. ${ }^{209}$

Según el autor, la obra tenía diez hojas y su poseedor "conservó como biombo propiamente dicho la cara que imitaba la laca de Coromandel [e] hizo restaurar la parte opuesta en forma de cuadro; pero debido a su tamaño, tuvo que dividirse la pintura en tres secciones, con cuatro hojas para la central y

209. Manuel Romero de Terreros, "El palacio de Chapultepec en I700", Anales del Instituto de Investigaciones Estéticas IV, núm. I3 (1945): 55-56. 




I6. Biombo achinado de doce hojas y dos haces. Nueva España, segunda mitad del siglo xviıI, $227 \times 540$ cm. Imagen cortesía del Museo Franz Mayer, México. Foto: Sonia I. Ocaña Ruiz.

tres para cada una de las laterales". ${ }^{210}$ La pieza sólo se reprodujo por el anverso tanto en la obra de Romero de Terreros como en el libro Biombos mexicanos. ${ }^{2 I I}$

Quizá el haz que imitaba la laca china haya tenido cierto parecido con el anverso de un biombo anónimo de doce hojas del Museo Franz Mayer (fig. 16), en cuyos extremos Gustavo Curiel ha observado enormes motivos florales de inspiración china, donde aparecen loros americanos. La escena transcurre en un sitio cercado que contiene pabellones de audaz arquitectura, un lago, ríos y montañas, así como personajes de alto rango que transitan bajo parasoles cargados por sirvientes, o van a caballo; además de músicos, grupos de cazadores, parejas y personajes que juegan, cuidan animales, pasean por el jardín o cargan viandas. La abundante fauna incluye una variedad de aves, mariposas, una tortuga asociada a una serpiente, un cangrejo, un tigre, liebres, un cebú, perros y ciervos. ${ }^{212}$

Pese al parecido con los biombos de laca chinos y achinados (figs. 2, 9, IIa y IIb), los modelos pueden haber venido de distintas fuentes, pues hay similitudes con las figuras de ciertas porcelanas japonesas y tratados europeos (fig. I7). Llama la atención el fondo azarcón, que quizá haya sido originalmente

2IO. Romero de Terreros, "El palacio de Chapultepec", 56.

2II. Castelló Yturbide y Martínez del Río de Redo, Biombos mexicanos, 94-96.

2I2. Curiel, "Al remedo de la China", 314-316. 
17. John Stalker y George Parker, A Treatise on Japanning and Varnishing (Londres, I688; reimpreso Londres, 1960, 1971). Imagen tomada de Kopplin, European Lacquer (vid supra n. IOO), 330.

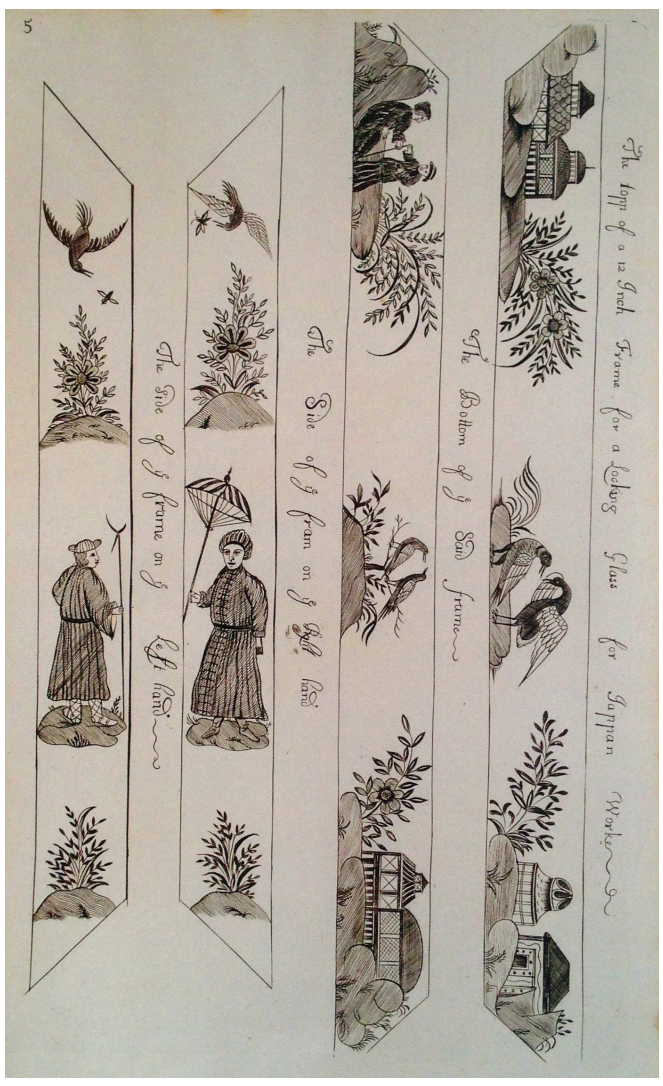

rojo, como los biombos antes discutidos. ${ }^{213} \mathrm{La}$ inclusión de figuras como los pericos sugiere que el comitente no exigió un repertorio exclusivamente achinado; pese a la voluntad de aproximarse a las soluciones asiáticas, "La arquitectura lejos está de parecerse a la china; los esquematismos, las estilizaciones y los estereotipos se hacen evidentes en pabellones y pagodas que tratan de semejarse a las asiáticas. Hay, pues, en estas construcciones, soluciones formales del

213. El color recuerda al de algunos maques de Olinalá. Sin embargo, en mi opinión se trata de una obra hecha en un taller de pintura. Un estudio técnico ayudaría a determinar en qué clase de taller se hizo la obra y su color original. Los cambios de color fueron frecuentes en las lacas europeas; véase Ordóñez Goded, “De lacas y charoles”, 97-98. 
barroco novohispano." ${ }^{214}$ Se conocen otros ejemplares parecidos al que nos ocupa; al margen del maque, las numerosas referencias documentales a biombos achinados podrían referirse a este tipo de obras. ${ }^{215}$ Es decir, el conocimiento fragmentario de las lacas asiáticas y las europeas achinadas dio pie a que los novohispanos concibieran distintas maneras de domesticarlas, por medio de una variedad de técnicas que no conocemos del todo.

\section{Conclusiones}

Aunque las respuestas sobre el consumo novohispano de maque chino y achinado aún son parciales y requieren estudios técnicos, ya empieza a vislumbrarse la amplia gama de posibilidades abiertas en relación con estos procesos. En el siglo XVIII, además de las lacas hechas por los carroceros, es posible que se hayan usado otras técnicas europeas, incluyendo aquéllas derivadas de las recetas para aficionados divulgadas por medio de manuales. Cabe esperar que futuros estudios sobre las lacas de técnica europea en la Nueva España contribuyan a la discusión sobre las lacas españolas, cuyo impacto en el ámbito local aún se desconoce.

El hecho de que las obras y técnicas europeas de laca hayan circulado y contribuido a moldear los gustos novohispanos de ninguna manera resta originalidad a estos últimos. $\mathrm{Al}$ respecto, destacan los biombos, que en Europa a menudo fueron desmontados, mientras que en la Nueva España se prefirió exhibirlos completos; su uso para aislar la cama es uno de los mejores ejemplos de que los novohispanos nunca se limitaron a copiar las modas europeas, e insistieron en domesticar los objetos chinos y achinados de modos propios.

Por otro lado, futuras investigaciones deberán profundizar en el análisis iconográfico de las lacas achinadas de Pátzcuaro, que podrían exhibir notable cercanía con los diseños europeos. Es probable que muchos consumidores novohispanos no distinguieran del todo la procedencia de las lacas achinadas; puesto que el gusto por las distintas producciones tenía un sustrato común, es lógico suponer que las lacas achinadas europeas no sólo se usaron como fuente de inspiración en los muebles de formas o técnicas informadas en ellas, sino también en las lacas de origen prehispánico.

2I4. Curiel, "Una caja de maque de Michoacán", 316.

215. Las obras se reproducen en Artes de México. El mueble mexicano, fig. 39, y en el catálogo El mueble mexicano. Historia, evolución e influencias (México: Fomento Cultural Banamex, 1985), fig. I64, respectivamente. 
El estudio de las lacas chinas y achinadas presenta un problema interesante: en España parecen conservarse más lacas asiáticas que europeas, mientras que en México se conservan pocas lacas asiáticas, pero su importancia se advierte en los documentos y en las numerosas obras informadas en las lacas chinas y japonesas. Esto prueba que el gusto por dichas obras se convirtió en un ingrediente más de las preferencias locales. Más que ofrecer respuestas definitivas, aquí se ha demostrado la necesidad de seguir estudiando el tema para conocer mejor el impacto de las lacas asiáticas en la Nueva España.

El significado de las lacas "chinas" para el público virreinal ${ }^{216}$ comprende un complejo entramado de identidades en tránsito el cual sin duda motivó el interés que estas obras generaron en sus consumidores. En el siglo XviII, los gustos artísticos se fincaron, en parte, en la posesión de dichas obras. Aunque los documentos novohispanos sugieren que a menudo se ignoraron los orígenes precisos y no se entendió la iconografía de las obras asiáticas, esta falta de conocimiento no impidió que se hicieran múltiples apropiaciones, pues los procesos de domesticación son independientes de la información sobre los objetos.

El consumo de lacas "chinas" en los ámbitos domésticos dio lugar a cierta familiarización que alimentó la construcción de distintas miradas hacia el otro y a sí mismo, pues al parecer la admiración por las obras asiáticas implicó el deseo de "mejorarlas". Recuérdese la conocida cita del padre Ajofrín, quien a su paso por Pátzcuaro (1763) advirtió: "Hoy florece un célebre pintor, indio noble, llamado don José Manuel de la Cerda, que ha perfeccionado mucho esta facultad, de suerte que excede en primor y lustre a los maques de China." ${ }^{217}$ La afirmación de la superioridad del trabajo de De la Cerda respecto a los maques chinos podría ser, más que una apreciación particular de Ajofrín, un indicio de que el éxito de los lacadores novohispanos se basó en su capacidad de satisfacer los gustos de un mercado proclive a dichas comparaciones. Este fenómeno es común a otras producciones ${ }^{218}$ y debe tenerse en cuenta al estudiar las implicaciones de la relación artística con Asia, que estuvo en constante redefinición. \$

216. Keating y Markey, “Indian' Objects”, I5.

217. Ajofrín, Diario del viaje, i6o (las cursivas son mías).

218. En 1760, en un pleito entre loceros de Puebla y Atlixco, uno de ellos se proclama "inventor de la loza que imita a la de China, y la fabrica perfecta; que ninguno de los más instruidos podrá distinguir la suya de la de China y la del Japón”. Enrique Cervantes, Loza blanca y azulejo de Puebla, t. I (México: edición del autor, 1939), 42. 


\section{Imaginería, ritualidad y poder en la plástica teotibuacana: una nueva aproximación a los conjuntos icónicos}

\section{Imagery, Rituality and Power in Teotihuacan Art: a New Approach to Iconic Clusters}

Artículo recibido el 8 de enero de 20I6; devuelto para revisión el 20 de julio de 20r6; aceptado el 9 de diciembre de 2016, http://dx.doi.org/IO.2220I/iie.18703062e.2017.III.2605

Tatiana Valdez Bubnova El Colegio Mexiquense, México. profesorambrosius@yahoo.com

Líneas de investigación Cultura teotihuacana, cultura náhuatl, textos de origen mesoamericano, semiótica visual.

Lines of research Teotihuacan culture, Nahuatl culture, Mesoamerican origin texts, visual semiotics.

Publicaciones más relevantes "Hacia una revisión de los posibles antecedentes teotihuacanos del estilo Mixteca-Puebla: aspectos temáticos”, en Juan José Batalla Rosado y Miguel Ángel Ruz Barrio, coords., Los códices mesoamericanos: registros de religión, politica y sociedad (México: El Colegio Mexiquense, 2016), 19-43; "La interpretación del objeto dinámico y el objeto inmediato en algunas clases de imágenes de la plástica teotihuacana", Estudios Mesoamericanos, vol. Io (2011): 25-38; "La Venta y la traza ideal de la ciudad temprana como paradigma del urbanismo teotihuacano", Memorias del 53 Congreso Internacional de Americanistas, CD, vol. I (2010); "El valor en la imagen gráfica teotihuacana. Reflexiones desde La Ventilla", Anales del Instituto de Investigaciones Estéticas XXX, núm. 92 (2008): 5-47.

Resumen Recientes descubrimientos arqueológicos en Teotihuacan permiten contrastar el potencial explicativo de las clasificaciones de la plástica disponibles con la evidencia reciente, y trascender la descripción formal, con interpretaciones del contenido sustentadas en estudios internos. $\mathrm{Al}$ incorporar descubrimientos recientes se presenta una clasificación temática de las imágenes visuales teotihuacanas y sus correlatos formales, en la cual se integran nuevos hallazgos. Las muestras se consideran como parte de un discurso religioso-ritual y cívico. Se argumenta que se trata de la expresión de una narrativa que se desarrolla en torno a tres ejes básicos: el culto, el mito y la identidad social. Cuando es posible, se señalan relaciones funcio- 
nales entre la imaginería y el urbanismo y se incluyen aspectos contextuales y temporales.

Palabras clave Teotihuacan; imagen; rito; mito; identidad; urbanismo.

Abstract Recent archaeological findings in Teotihuacan serve to contrast the available explanatory potential of imagery classifications with new evidence in order to transcend formal descriptions and propose interpretations sustained by internal studies. Incorporating recent discoveries, this paper presents a classification of visual images at Teotihuacan according to their themes and formal correlates. The samples are understood as components of religious-ritual and civic discourse. It argues that it is the expression of a narrative developed around three basic axes: the cult, the myth and social identity. Where possible, functional relationships between imagery and urbanism are identified and contextual and temporal aspects are included.

Keywords Teotihuacan; image; rite; myth; identity; urbanism. 